\title{
Drought impact on rainfed common bean production areas in Brazil
}

\author{
Alexandre B. Heinemann ${ }^{\mathrm{a}, *}$, Julian Ramirez-Villegas ${ }^{\mathrm{b}, \mathrm{c}, \mathrm{d}}$, Thiago Lívio P. O. Souza ${ }^{\mathrm{a}}$, \\ Agostinho Dirceu Didonet $^{a}$, Jose Geraldo di Stefano ${ }^{a}$, Kenneth J. Boote ${ }^{\mathrm{e}}$, Andy Jarvis ${ }^{\mathrm{b}, \mathrm{c}}$ \\ a Embrapa Rice E' Beans Rodovia GO-462 km 12 Zona Rural, 75375-000 Santo Antônio de Goiás, GO, Brazil \\ b International Center for Tropical Agriculture (CIAT), Km. 17 Recta Cali-Palmira A.A. 6713, Cali, Colombia \\ ${ }^{\mathrm{c}}$ CGIAR Research Program on Climate Change, Agriculture and Food Security (CCAFS), Cali, Colombia \\ d School of Earth and Environment, University of Leeds, Leeds, UK \\ e Agronomy Dep., University of Florida, P.O. Box 110500, Gainesville, FL 32611, United States
}

\section{A R T I C L E I N F O}

\section{Article history:}

Received 16 September 2015

Received in revised form 16 February 2016 Accepted 9 May 2016

\section{Keywords:}

Breeding

Modeling

Water deficit

Environment classification

Phaseolus vulgaris $\mathrm{L}$.

\begin{abstract}
A B S T R A C T
Common bean production in Goiás, Brazil is concentrated in the same geographic area, but spread across three distinct growing seasons, namely, wet, dry and winter. In the wet and dry seasons, common beans are grown under rainfed conditions, whereas the winter sowing is fully irrigated. The conventional breeding program performs all varietal selection stages solely in the winter season, with rainfed environments being incorporated in the breeding scheme only through the multi environment trials (METs) where basically only yield is recorded. As yield is the result of many interacting processes, it is challenging to determine the events (abiotic or biotic) associated with yield reduction in the rainfed environments (wet and dry seasons). To improve our understanding of rainfed dry bean production so as to produce information that can assist breeders in their efforts to develop stress-tolerant, high-yielding germplasm, we characterized environments by integrating weather, soil, crop and management factors using crop simulation models. Crop simulations based on two commonly grown cultivars (Pérola and BRS Radiante) and statistical analyses of simulated yield suggest that both rainfed seasons, wet and dry, can be divided in two groups of environments: highly favorable environment and favorable environment. For the wet and dry seasons, the highly favorable environment represents $44 \%$ and $58 \%$ of production area, respectively. Across all rainfed environment groups, terminal and/or reproductive drought stress occurs in roughly one fourth of the seasons (23.9\% for Pérola and $24.7 \%$ for Radiante), with drought being most limiting in the favorable environment group in the dry TPE. Based on our results, we argue that even though drought-tailoring might not be warranted, the common bean breeding program should adapt their selection practices to the range of stresses occurring in the rainfed TPEs to select genotypes more suitable for these environments.
\end{abstract}

(ㄷ) 2016 Elsevier B.V. All rights reserved.

\section{Introduction}

Beans are considered the most important grain legume for direct human consumption worldwide, with a global production of ca. $23000 \mathrm{t}$ (FAOSTAT, 2015). Among bean species, those of the genus Phaseolus are the most widely grown, occupying more than $85 \%$ of bean production area globally (Singh, 2001). Phaseolus vulgaris L.,

\footnotetext{
* Corresponding author.

E-mail addresses: alexandre.heinemann@embrapa.br (A.B. Heinemann), j.r.villegas@cgiar.org (J. Ramirez-Villegas), thiago.souza@embrapa.br (T.L.P.O. Souza), agostinho.didonet@embrapa.br (A.D. Didonet), jose.distefano@embrapa.br (J.G. di Stefano), kjboote@UFL.EDU (K.J. Boote), a.jarvis@cgiar.org (A. Jarvis).
}

hereafter referred to as common bean, accounts for $80 \%$ of the bean species consumed (Wander, 2007). Common bean is cultivated in a wide range of production systems, representing different climates, soils, cultivars and levels of technology.

Brazil is the largest world edible bean producer and consumer ( 2.5 million ton in 2013-IBGE, 2015; Thung and Rao, 1999; FAOSTAT, 2015). Beans constitute a primary source of protein in the diet of the Brazilian population (per capita consumption estimated at $17.8 \mathrm{~kg} \mathrm{year}^{-1}$ ) (Embrapa Arroz e Feijão, 2015). Rainfed systems represent $93 \%$ ( 2.8 million ha) of common bean Brazilian production area (IBGE, 2015). In the state of Goiás, one of the main bean-producing states in Brazil and the focus of this paper, crop production is concentrated in the same geographic area, but spread across three distinct growing seasons, namely wet (sowing 


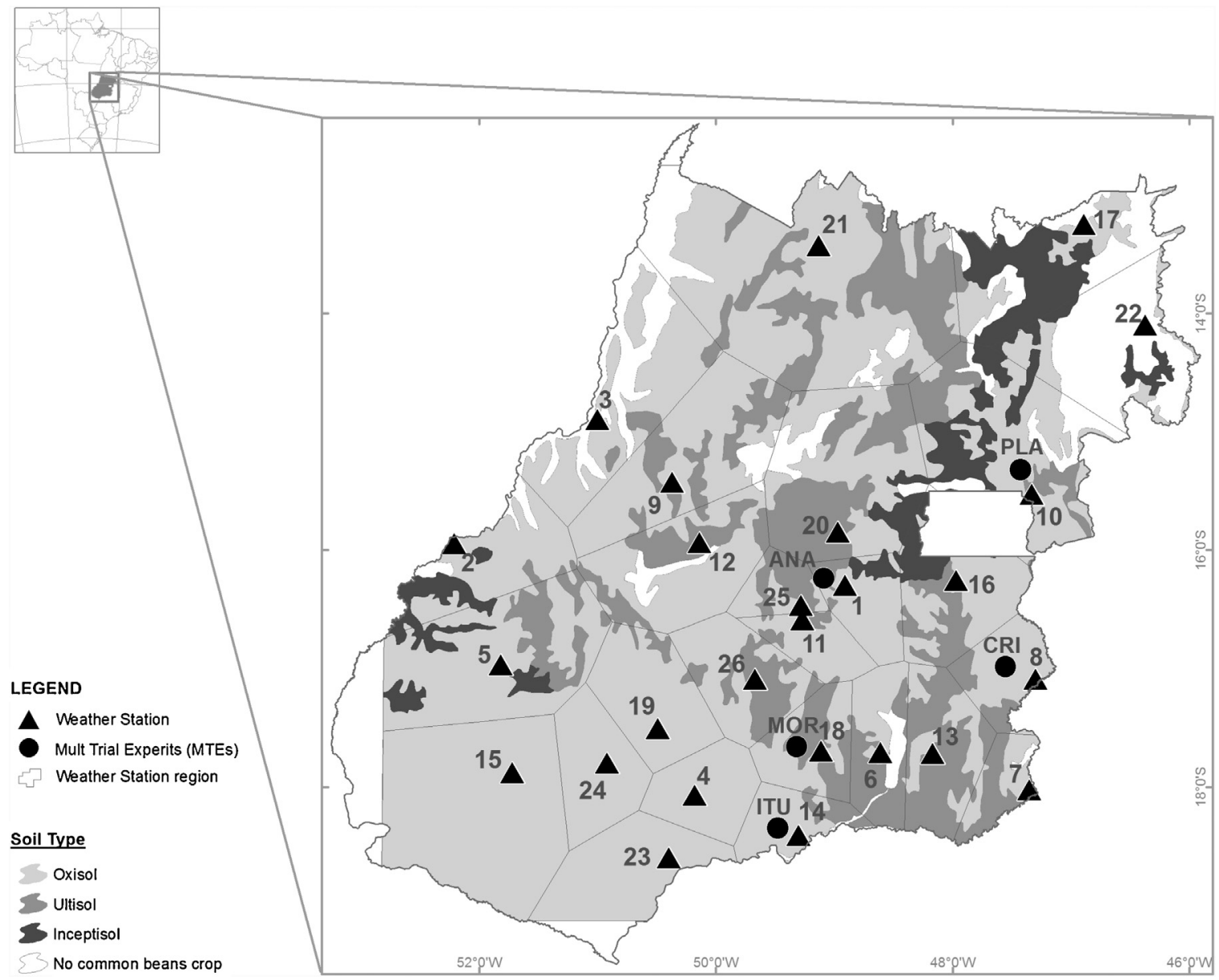

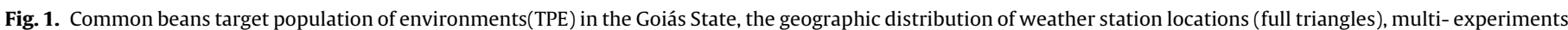

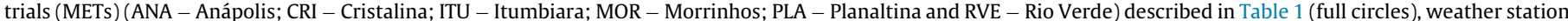

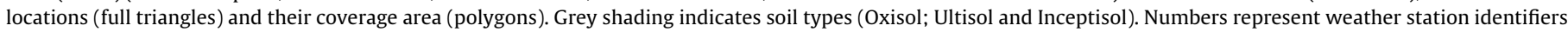
described in Supplementary Table S1. Zoom window shows the Goiás TPE localization in Brazil.

from 1 Nov to $31 \mathrm{Dec}$ ), dry (sowing from 01 Jan to $28 \mathrm{Feb}$ ) and winter (sowing from 1 May to 30 Jun). In the wet and dry seasons, common beans are grown under rainfed conditions, whereas the winter sowing is fully irrigated. Due to environmental variability, the performance of cultivars varies substantially across seasons, with average yield being 1700,1500 and $2700 \mathrm{~kg} \mathrm{ha}^{-1}$ for the wet, dry and winter seasons, respectively (IBGE, 2015). The differences in yield between the winter and the two rainfed (wet and dry) seasons imply the occurrence of stresses that limit crop productivity (Beebe et al., 2011).

Common bean crops grown in the rainfed seasons (wet and dry) suffer from both abiotic and biotic production constraints. The most widespread abiotic constraints are low soil fertility, drought (Beebe et al., 2011; Müller et al., 2014; Singh, 2001) and nitrogen deficiency due to poor nitrogen fixation (Rao, 2001). Additionally, several bacterial, fungal, and viral diseases reduce bean production (Barcelos et al., 2014; Beebe et al., 2011; Melo et al., 2012; Singh and Schwartz, 2010; Souza et al., 2013-see Supplementary Table 1). In fact, currently, a major limitation for growing bean in the dry season is an increase in the prevalence of whitefly (Bemisia tabaci), vector of the bean gold mosaic virus (BGMV), due to mainly soybean harvest (whiteflies are forced to migrate to other crops such as common bean). The development of stress resistant cultivars has typically been a successful strategy to counter the yield impacts of both biotic and abiotic stresses (Araujo et al., 2015).

Generally, conventional common bean breeding programs focus largely on developing germplasm for local needs as the most appro- priate strategy for developing adapted cultivars for a range of environments (Kelly and Cichy, 2013). Conversely, the Brazilian common bean breeding program led by Embrapa's Rice and Beans unit focuses on broad adaptation for all Brazilian bean production regions. The early generation screening yield trials (nursery) in the Goiás State are performed only in the winter season under wellwatered conditions (i.e. fully irrigated) and target mainly direct selection for grain yield (Melo, 2009). This means that, as in other Brazilian breeding programs (e.g. upland rice, Heinemann et al., 2015), common bean genotype selection under the winter irrigated scheme may increase the risk of developing genotypes specialized for highly favorable environments and which lack plasticity and hence perform poorly under stress. Due to the range of stresses and their interactions in the rainfed seasons, it is currently unclear to breeders what the major constraints that affect the crop are and how those constraints vary spatiotemporally. As most bean production occurs under low input agriculture on small-scale farms, knowledge of the major constraints that affect the crop in rainfed seasons is critical for developing technologies and knowledge for yield improvement (De Luque and Creamer, 2014).

In this study, we applied a characterization of environments that integrates weather, soil, crop and management factors using a crop simulation model, with the aim of producing information that can assist breeding strategies in their efforts to develop stress-tolerant high-yielding germplasm for the rainfed seasons (Chapman 2008; Chauhan et al., 2013; Chenu, 2014; Heinemann et al., 2015; Löffler et al., 2005). Our specific objectives were to (a) develop a charac- 
terization of environments and drought stress levels in the state of Goiás for both rainfed seasons, (b) quantify the drought impact on common bean in these seasons, and (c) suggest new breeding strategies that address drought stress in the rainfed seasons and therefore improve current productivity levels.

\section{Materials and methods}

\subsection{Study region}

The study region, located in the Goiás state in central Brazil, with a surface area of $340,086 \mathrm{~km}^{2}$, a range in altitude of $400-1300 \mathrm{~m}$ and latitude and longitude from $-12.8^{\circ}$ to $-19.5^{\circ} \mathrm{S}$ and $-49.0^{\circ}$ to $-50.9^{\circ} \mathrm{W}$ (Fig. 1 ). The annual climate of the study area corresponds to the Köppen climate classification category "Aw" (i.e. tropical wet and dry or savannah climate), with mean annual precipitation of $1000-1500 \mathrm{~mm}$ (mono-modal summer rains). Common bean production in the period 2001-2010 was distributed as follows: $37 \%$ (wet), 23\% (dry), and 40\% (winter) seasons (IBGE, 2015). Sowing for the wet (dry) season occurs between the beginning of November (January) and the end of December (February). In spite of both rainfed seasons showing sequential sowing dates, they are characterized by having different climate conditions and consequently different varietal performance. The dry season shows a lower potential yield than wet season due to a decrease in the accumulated radiation and a higher frequency of lower-thanoptimal minimum temperature during the crop cycle (Heinemann and Stone, 2015). Compared to the winter season, the rainfed (wet and dry) seasons have a higher level of climate-driven biotic and abiotic stress, and a high predominance of small-scale farms and low input agriculture, as a response to high agro-climatic risk. On the other hand, the winter season (not studied here) is characterized by low biotic and abiotic (lower temperatures and humidity) pressure and higher level of technology (fully irrigated and high fertilizer use rates) and its sowing window is between May and June. The naming of the three seasons (i.e. wet, dry, winter) is a result of many factors: radiation, temperature, soil water balance, all of which affect the performance of cultivars and cause each season to be a distinct set of environments (Comissão Técnica Sul-Brasileira de Feijão, 2010; Informações técnicas para o cultivo do feijoeiro-comum na região central-Brasileira, 2012). In fact, for a new cultivar to be released, the breeding program must specify which season (wet, dry or winter) the new cultivar is adapted to, at the Brazilian Ministry of Agriculture, Cattle and Supplying (MAPA; www.agricultura.gov.br/politica-agricola/ zoneamento-agricola/cultivares-de-zoneamento-por-safra). Similarly, the common bean breeding program led by Embrapa Rice and Beans applies this classification for multi-environment experiment (MET) allocation. In this context, and based on the definition of Target Population of Environments (TPE): “a set of environments, including spatial and temporal variability, to which improved crop varieties developed by a breeding program need to be adapted" (Nyquist, 1991; Cooper et al., 1997; Heinemann et al., 2008), in this study as well as in Brazil, the wet, dry and winter seasons are considered individual TPEs. The focus of this study will be only the two rainfed TPEs (wet and dry) because the Embrapa common bean program already performs genotype selection in the winter TPE.

\subsection{Observed data}

\subsubsection{Weather and soil data}

Twenty-six sites with available daily weather data in Goiás, where common bean is currently grown, were selected within the TPE for further analyses. Historical daily weather data, i.e., precipitation, maximum and minimum temperatures, were gathered from the INMET website (Brazilian Meteorological Institute, available at http://www.inmet.gov.br) for each of the 26 sites and checked for gaps and inconsistencies following D'Afonseca et al. (2012, 2013a,b) (Supplementary Table S1). Daily global solar radiation for all weather stations, except one station (ID $=24$, Supplementary Table S1) was estimated following the method of Richardson and Wright (1984). The area of influence of each weather station was determined by drawing Thiessen polygons, as this allowed performing spatially explicit crop simulations (Heinemann et al., 2002, 2015).

The three most prevalent agricultural soils, i.e. Oxisol, Ultisol and Inceptisol, in the production region were then selected from the IBGE soil map http://mapas.mma.gov.br/i3geo/mma/openlayers. htm, (see Fig. 1 for soil type distribution). Oxisols, Ultisols and Inceptisols represent 64,19 and $6 \%$ of the agricultural area in the Goiás state, respectively. To create three soil scenarios (Oxisol, Ultisol and Inceptisol) for simulations, physical soil proprieties for each soil type were gathered from the Brazilian soil database (Benedetti et al., 2008; available at http://www.esalq.usp.br/gerd/ BrazilSoilDB_08VI05.xls). This database represents well all soil classes of Brazil regardless of their land-use (5479 profiles and 10,950 horizons throughout the country). Given the wide coverage of the data for Goiás and the quality of the information (see Benedetti et al., 2008), this database was deemed appropriate for the analyses conducted here (see Heinemann et al., 2015). These data were then used to derive soil hydrological properties following the same procedure applied by Heinemann et al. (2015) (Supplementary Table S3 describes physical and hydrological soil properties). The available water content (AWC) was $0.813,0.476$ and $0.588 \mathrm{~mm} / \mathrm{cm}$ for Oxisols, Ultisols and Inceptisols, respectively. In the literature, for Savannah region soils, the AWC for Oxisols, Inceptisol and Ultisol are described ranged from $0.75-1.00,0.46-0.60$ and $0.48-0.77 \mathrm{~mm} / \mathrm{cm}$, respectively (www. pedologiafacil.com.br/enquetes/enq54.php; Assis et al., 2015; Reatto et al., 2000; Spera et al., 2005). The effective soil root depth is 60 (Oxisol), 40 (Ultisol) and 40 (Inceptisol) cm and, as the other soil physical and hydrological properties, was derived from a large number of soil profiles: 93 (Oxisol), 51 (Ultisol) and 31 (Inceptisol), as described in Supplementary Table S3.

\subsubsection{Common bean trial data}

Four sets of experiments were used in the present study. The first set was used for model parameterization, whereas the second, third and fourth sets were used for model evaluation. Model parameterization experiments (PGE, hereafter) were performed at Embrapa Rice and Bean experimental station located at Santo Antônio de Goiás, GO, (latitude: -16.47 ; longitude: -49.28 , elevation: $715 \mathrm{~m}$; location ID $=24$ in Supplementary Table S1) during the winter seasons of 2011 (planted 15 Jun) and 2012 (planted 22 May, 8 Jun, 20 Jun and 4 Jul, Table 1 ).

These experiments were selected because they had the lowest effects of abiotic and biotic stresses. In these experiments, basal fertilizers at sowing date were applied at the rate of 120 and $60 \mathrm{~kg} \mathrm{ha}^{-1}$ of phosphorous $(\mathrm{P})$ and potassium $(\mathrm{K})$, respectively. Nitrogen $(\mathrm{N})$ was split-applied as follows: basal at sowing date, topdressing at V3 (third trifoliate unfolds) and at the end of V4 (fourth trifoliate), at the rate of 20 (first application), 30 (second) and 50 (third) $\mathrm{kg}$ $\mathrm{ha}^{-1}$, following typical farmer management practices in the region. These experiments were fully irrigated and were used for phenology and growth parameterization. For phenology, measurements of planting date, emergence dates, flowering, first pod, first seed and physiological maturity were used. For growth parameterization, measurements of leaf area index (LAI), leaf, stem, pod biomass and yield were used.

The second set of experiments, referred to as EVAL, consisted of 11 experiments conducted during the period of 2011-2013 
Table 1

Experimental data used in this study based for both Pérola and Radiante genotypes.

\begin{tabular}{|c|c|c|c|c|c|}
\hline Name & Description $^{1}$ & Cultivars & Measured variables used & Used for & Site \\
\hline \multirow[t]{5}{*}{ PGE } & (1) Planting 15/06/2011 (I) & Both & $\begin{array}{l}\text { sowing date; planting date; } \\
\text { flowering date; first pod date; } \\
\text { first seed date; leaf, stem and } \\
\text { pod biomass; leaf area index } \\
\text { (LAI)and yield. }\end{array}$ & $\begin{array}{l}\text { Phenology calibration and } \\
\text { growth parameter calibration }\end{array}$ & SAG \\
\hline & (2) Planting 22/05/2012 (I) & Both & & & \\
\hline & (3) Planting 08/06/2012 (I) & Both & & & \\
\hline & a(4) Planting 20/06/2012 (I) & Both & & & \\
\hline & (5) Planting 04/07/2012 (I) & Radiante & & & \\
\hline \multirow[t]{11}{*}{ EVAL1 } & (1) Planting 29/06/2011 (I) & Both & $\begin{array}{l}\text { sowing date; planting date; } \\
\text { flowering date; first pod date; } \\
\text { first seed date; total biomass at } \\
\text { flowering, harvest day; and } \\
\text { pod biomass }\end{array}$ & Model evaluation & SAG \\
\hline & (2) Planting 13/07/2011 (I) & Both & & & \\
\hline & (3) Planting 28/07/2011 (I) & Both & & & \\
\hline & (4) Planting 24/01/2012 (I) & Both & & & \\
\hline & (5) Planting 28/02/2012 (I) & Both & & & \\
\hline & (6) Planting 30/03/2012 (I) & Both & & & \\
\hline & (7) Planting 23/04/2012 (I) & Both & & & \\
\hline & (8) Planting 04/07/2012 (I) & $\mathrm{P}$ & & & \\
\hline & (9) Planting 19/11/2012 (I) & Both & & & \\
\hline & (10) Planting $05 / 07 / 2013$ (I) & $\mathrm{P}$ & & & \\
\hline & (11) Planting $17 / 05 / 2013$ (I) & $\mathrm{P}$ & & & \\
\hline \multirow[t]{9}{*}{ EVAL2 } & (1) Planting 29/06/2011 (I) & $\mathrm{P}$ & yield & Model evaluation & SAG \\
\hline & (2) Planting 13/07/2011 (I) & Both & & & \\
\hline & (3) Planting 28/07/2011 (I) & Both & & & \\
\hline & (4) Planting 28/02/2012 (I) & $\mathrm{P}$ & & & \\
\hline & (5) Planting 23/04/2012 (I) & Both & & & \\
\hline & (6) Planting 08/06/2012 (I) & $\mathrm{P}$ & & & \\
\hline & (7) Planting 30/03/2012 (I) & $\mathrm{R}$ & & & \\
\hline & (8) Planting 20/06/2012 (I) & $\mathrm{R}$ & & & \\
\hline & (9) Planting 19/11/2012 (I) & $\mathrm{R}$ & & & \\
\hline \multirow[t]{2}{*}{ DRO } & (1) Planting 17/05/2013 (D) & Pérola & $\begin{array}{l}\text { sowing date; total biomass; LAI } \\
\text { and soil humidity from } 0 \text { to } \\
40 \mathrm{~cm} \text {. }\end{array}$ & $\begin{array}{l}\text { Model evaluation under } \\
\text { drought }\end{array}$ & SAG \\
\hline & (2) Planting 05/07/2013 (D) & Pérola & & & \\
\hline \multirow[t]{14}{*}{ MET } & (5) Planting 20/05/2011 (I) & Pérola & yield & $\begin{array}{l}\text { Model evaluation different } \\
\text { sites }\end{array}$ & ANA \\
\hline & (6) Planting 19/07/2004 (I) & Pérola & & & ANA \\
\hline & (7) Planting 05/05/2004 (I) & Pérola & & & MOR \\
\hline & (8) Planting 29/06/2007 (I) & Radiante & & & PLA \\
\hline & (9) Planting 19/05/2004 (I) & Radiante & & & RVE \\
\hline & (10) Planting 28/05/2003 (I) & Radiante & & & RVE \\
\hline & (11) Planting 06/02/2004 (I) & Radiante & & & CRI \\
\hline & (12) Planting 23/04/2008 (I) & Radiante & & & ITU \\
\hline & (13) Planting 09/06/2011 (I) & Radiante & & & ANA \\
\hline & (14) Planting 05/05/2004 (I) & Radiante & & & MOR \\
\hline & (15) Planting 05/07/2007 (I) & Radiante & & & PLA \\
\hline & (16) Planting 22/05/2003 (I) & Radiante & & & CRI \\
\hline & (17) Planting 28/05/2004 (I) & Radiante & & & RVE \\
\hline & (18) Planting 06/02/2004 (I) & Radiante & & & CRI \\
\hline
\end{tabular}

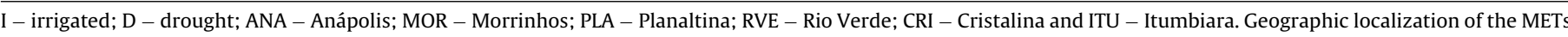
is shown in Fig. 1.

a not used for yield parameterization.

(Table 1). All trials were conducted at Santo Antônio de Goiás, GO (see Fig. 1) and were fully irrigated with the same fertilizer application rates and timings as the PGE experiments. The EVAL experiments were divided into EVAL1 (Table 1), used for evaluating phenology (flowering, first pod, first seed and physiological maturity), growth (dry matter at flowering and pod dry matter) and biomass dynamics (leaf, stem, pod and leaf area index), and EVAL2 (Table 1), used for yield evaluation. These experiments helped capture a range of planting dates.

The third set of experiments (DRO, hereafter) consisted of two trials sown 17 May 2013 and 05 Jul 2013. In both trials, drought stress was induced at 40 days after planting. The drought was clas- sified as moderate and severe for the first and second sowing dates, respectively. For the first sowing date, at the end of autumn, the plant water demand was lower due to lower temperatures, compared to the second sowing date (at the end of winter). This set of experiments was used to evaluate the performance of the crop model under drought levels. In particular, we assessed the skill of the model to simulate the dynamics of total dry biomass, leaf area index and soil water content.

The fourth set of experiments, referred to as MET (Table 1) was a data set of the multi-environment trials of the common bean breeding program from 2003 to 2011 across sites (Anapolis, Morrinhos, Planaltina, Rio Verde, Cristalina and Itumbiara, see Fig. 1) in the 

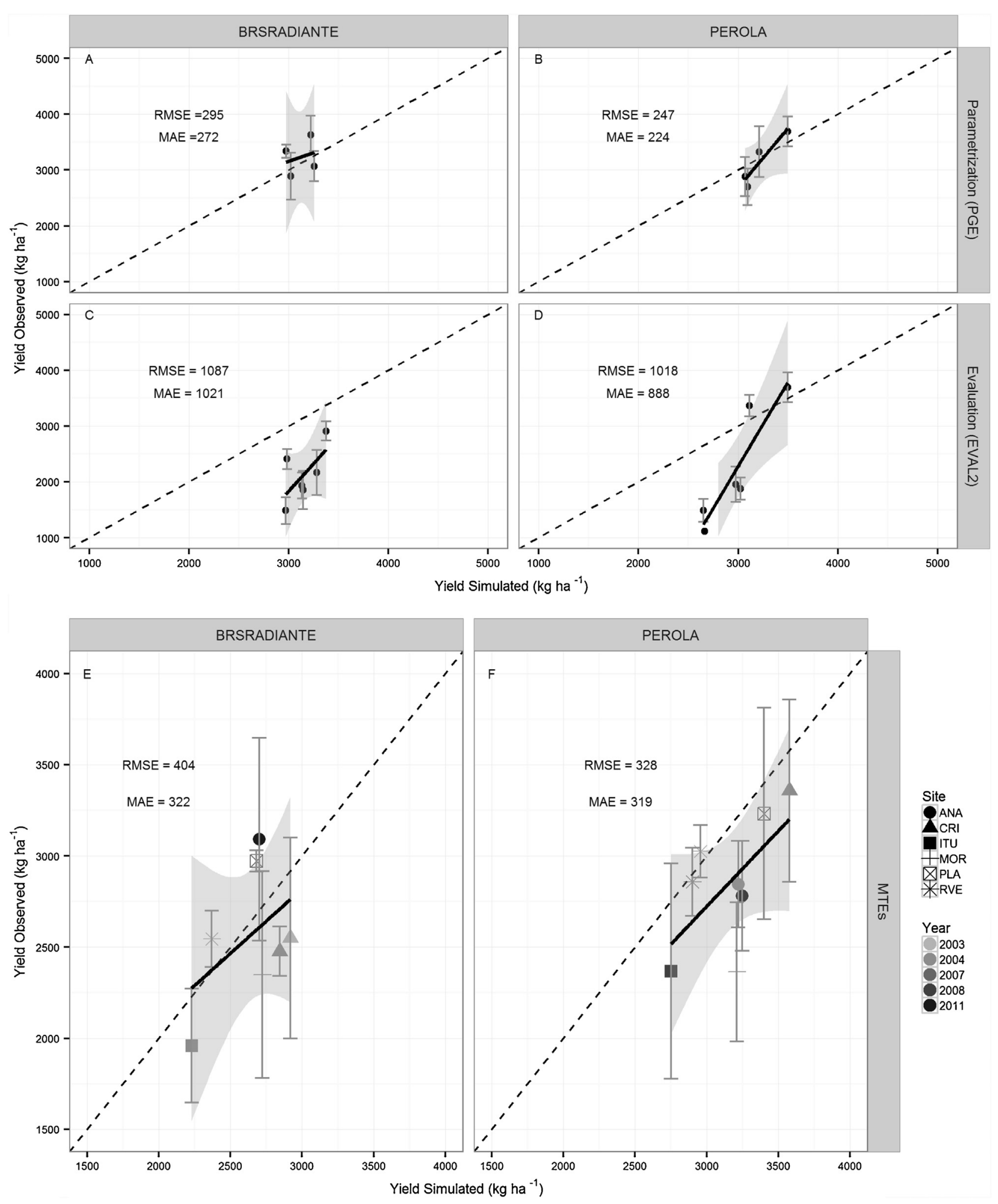

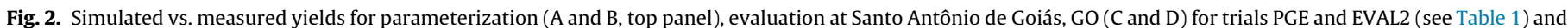

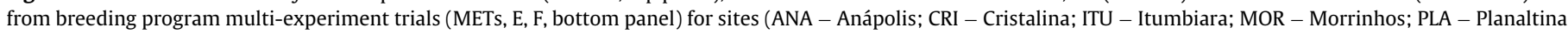

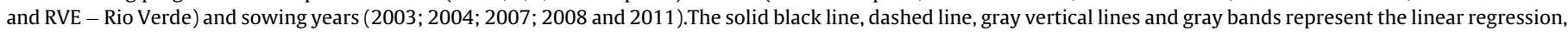
1:1 line, standard deviation and the $95 \%$ confidence interval, respectively. RMSE - root mean squared error and MAE - mean absolute error.

Goiás State. The experiments were fully irrigated. Reported data were only yield and sowing date. As management data were missing from the MET dataset, we assumed automatic irrigation to be applied at a rate of $20 \mathrm{~mm}$ of water when the top $30 \mathrm{~cm}$ of soil was below $50 \%$ of field capacity, following farmers' common practice. Table 1 presents a summary of experiments, variables reported and their use in this study. 

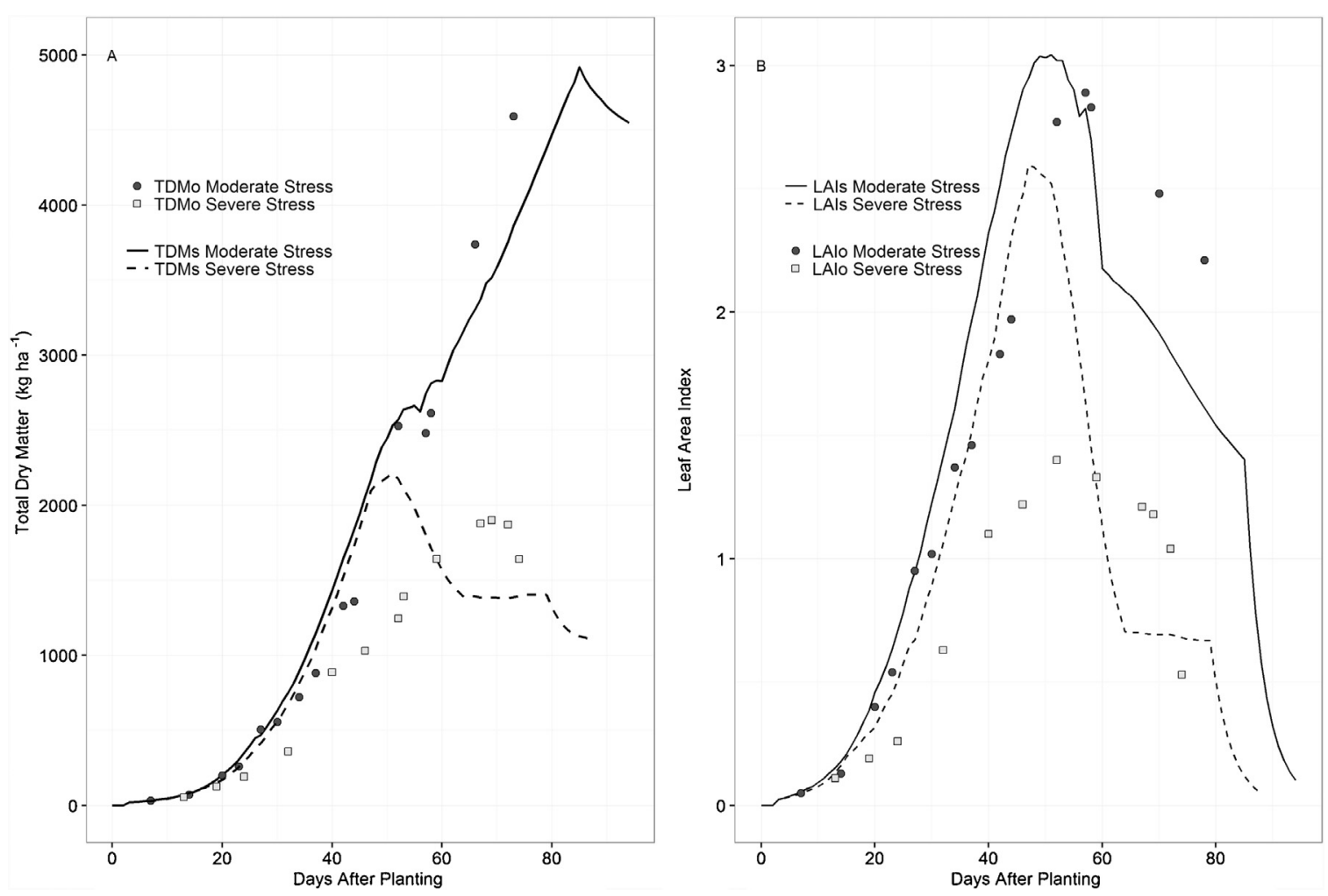

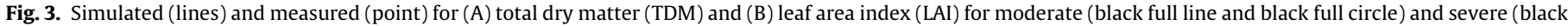
dashed line and open square) drought stress for cultivar Pérola. Observations are from the DRO dataset (see Table 1).

\subsection{Model parameterization and evaluation}

\subsubsection{Crop model}

The CSM-CROPGRO-DRY BEAN crop model is a process-oriented computer model that simulates growth, development and yield of common bean (Phaseolus vulgaris L.) as a function of environmental conditions, crop management and cultivar-specific parameters (Hoogenboom et al., 1992; Jones et al., 2003). We use the CSMCROPGRO-DRY BEAN model as it has been used broadly across Brazil (Heinemann et al., 2000, 2002; Lima Filho et al., 2013a,b; Oliveira et al., 2012). The model operates at a daily time-step and provides outputs for crop growth and development and for soil and plant water, nitrogen and carbon balances (Heinemann et al., 2002). A daily soil water balance (SWB) computes all processes that directly affect the water content in the soil profile throughout the season, using a tipping bucket approach to determine water infiltration and soil water content in successive soil layers (Ritchie, 1998). Potential evapotranspiration is based on the Priestley-Taylor evapotranspiration method.

Under drought stress, three relative stress factors act to limit plant growth. The TURFAC factor reduces expansive growth if total potential root water uptake is $<1.5$ times the potential transpiration. The SWFAC factor reduces photosynthesis when total potential root water uptake is less than the potential transpiration. The last stress factor acts to increase biomass partitioning to the roots when the ratio of actual transpiration relative to potential transpiration is < 1 (Hoogenboom et al., 1992; Jones et al., 2003; Ritchie, 1998; Webber et al., 2010).

\subsubsection{Model parameterization}

The CSM-CROPGRO-DRY BEAN crop model was parameterized for two standard check cultivars, Pérola and BRS Radiante (Radiante, hereafter), that are representative of varieties cultivated in
Central Brazil during the last ten years (both Pérola and Radiante are commonly used check varieties in breeding trials). Pérola has a Carioca larger grain type, the market class that represents about $70 \%$ of the Brazilian grain consummation, and Radiante has a small sugar grain type that represents the market class for export (Faria et al., 2003). The cultivars contrast in growth habit (Pérola-indeterminate growth habit and Radiante-determinate growth habit), growth cycle, plant architecture (Pérola-semiupright and Radiante - upright), pod filling time, and radiation use efficiency (Pérola: 1.04 and Radiante: $1.52 \mathrm{~g} \mathrm{MJ}^{-1}$ ) (Teixeira et al., 2015).

Crop development parameters from emergence to flowering (EM-FL), flowering to first pod (FL-SH), flowering to first seed (FL-SD) and first seed to physiological maturity (SD-PM) were calculated using the observed crop phenology data from the PGE field experiments (see Table 1). Based on our empirical field knowledge, both cultivars were assumed to have no photoperiod sensitivity. Due to the lack of observations, the parameters SDPRO and SDLIP, related to the fraction protein and oil in seeds (respectively), were set to those of cultivar Carioca in the model's database. The seed size (WTPSD), average seed per pod (SDPDV), both under standard growing conditions, and the maximum ratio of seed/(seed + shell) weight (THRSH) at maturity parameters were set based on the PGE dataset. XFRT (maximum fraction of daily growth partitioned to seed and pod) was set as 1 for both cultivars.

For deriving the cultivar-specific characteristics of crop growth, we applied a parameter estimation hybrid method based on the Metropolis-Hastings algorithm with a Gibbs sampler (Alderman et al., 2015). To reduce the risk of related growth parameters absorbing each other's errors, we followed a sequential approach, first optimizing the growth parameters LFMAX (maximum leaf photosynthesis rate) and PODUR (photo-thermal time required to reach final pod load) based on observations of total crop, stem, leaf, 


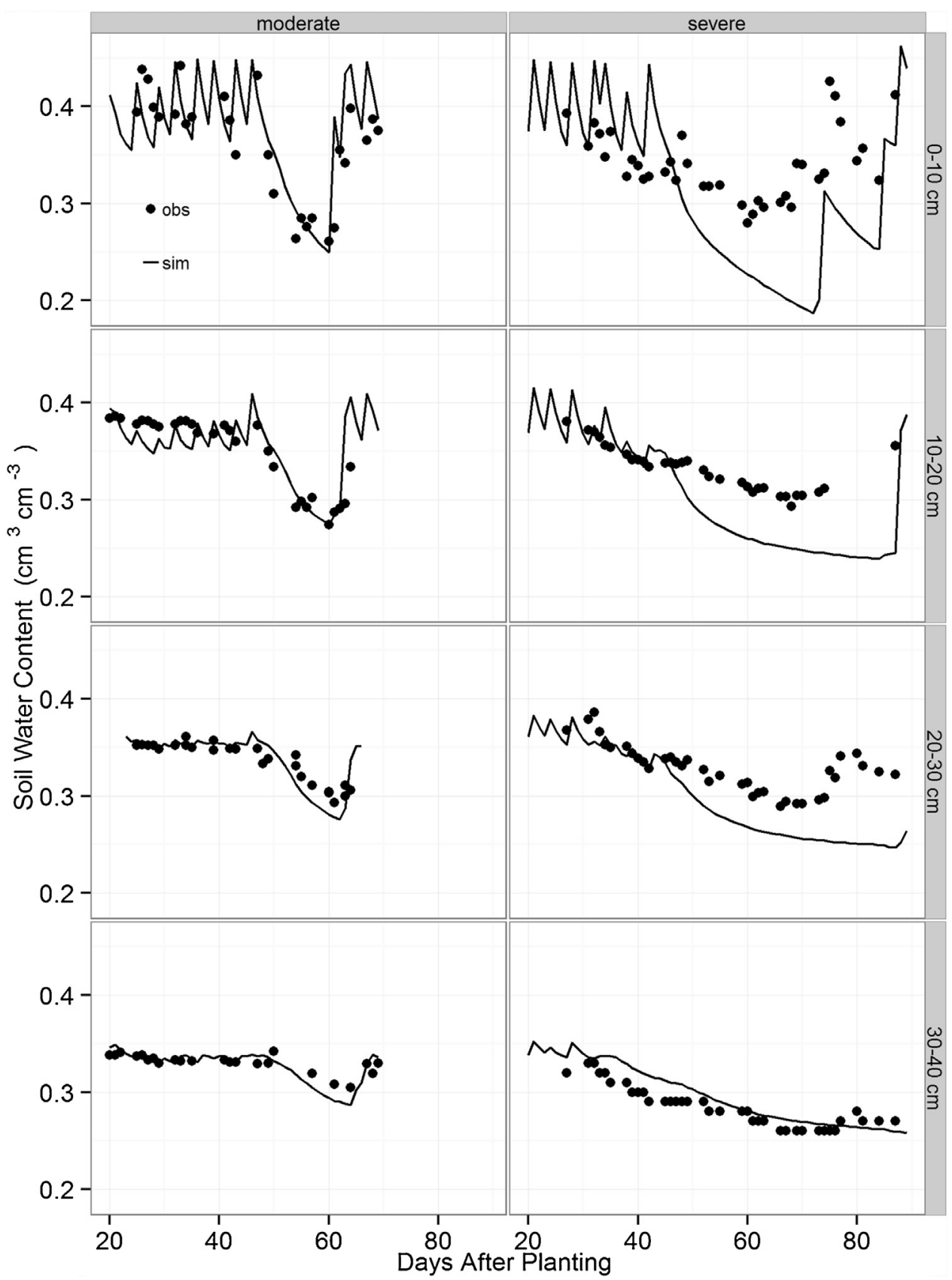

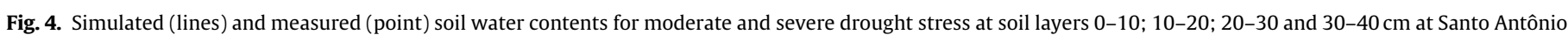
de Goiás, GO, Brazil, for common beans induced drought stress experiment (DRO - Table 1).

and pod biomass and pod index (pod biomass/tops biomass). Next, we optimized the SLAVR (specific leaf area under standard conditions) parameter. After the automatic procedure, we refined the calibration with a manual and iterative approach based on reducing the difference between simulated and observed leaf area index (LAI), as well as total crop, leaf, stem and pod biomass. Parameterization and evaluation were performed with both water and nitrogen balances turned on.

\subsubsection{Model evaluation}

Model evaluation focused on assessing the differences between simulated and observed values of the variables measured in the EVAL (both cultivars), DRO (only Pérola) and MET (both cultivars) datasets. Table 1 lists the variables that were assessed, which varied depending on the dataset used. The root mean square error (RMSE) and mean absolute error (MAE) were used as measures of model skill.

\subsection{Environmental characterization}

\subsubsection{Model simulations}

Crop simulations were performed for a total of 13 sowing dates across both rainfed seasons, for each of the three soil types, and 26 weather station regions for the period 1980-2013, using recommended agronomic practices for the region (cultivar, sowing dates, seed depth and row spacing). Sowing dates were defined at 10-day intervals for the wet (from 1 Nov to $30 \mathrm{Dec}$ ) and the dry (from 10 Jan to 28 Feb) TPEs, based on the climatic-risk zoning for the com- 

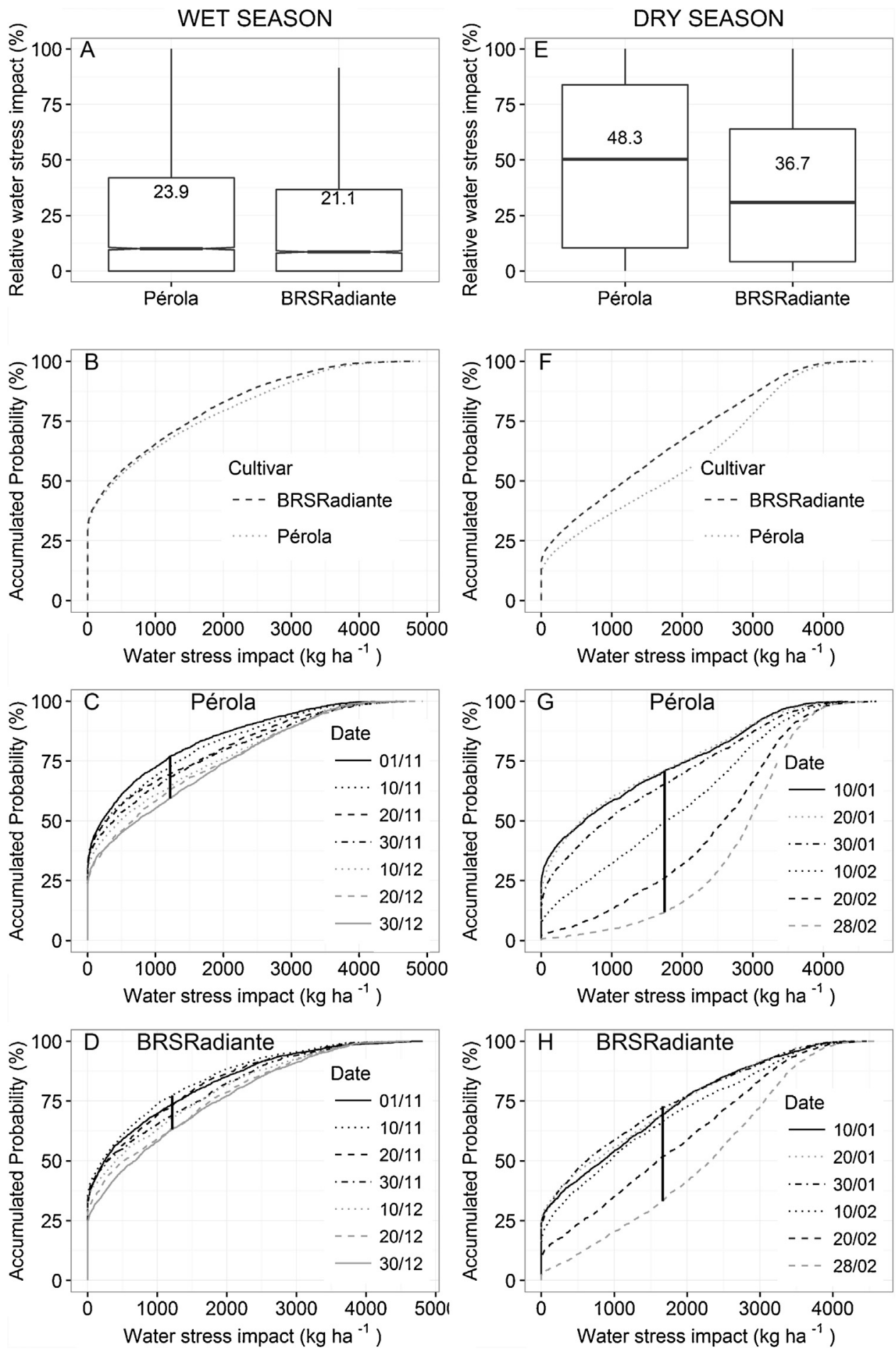

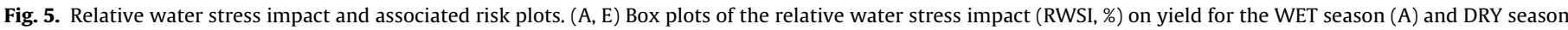

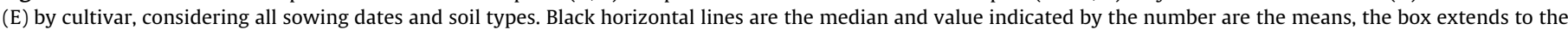

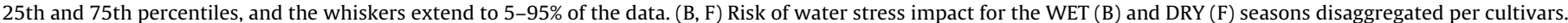

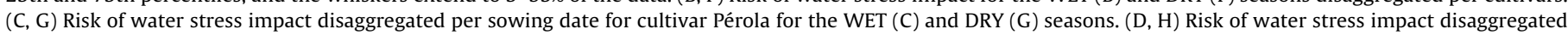

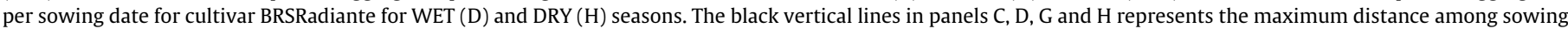
dates.

mon bean developed by the Brazilian Government (http://www. agricultura.gov.br). For each calendar year, model runs were initiated on the previous year, regardless of sowing date, in order to allow for establishing the soil water profile on the basis of rainfall patterns occurring before the actual sowing date. Simulations were performed for yield potential $\left(Y_{n s}\right.$, i.e., well-watered) and for water-limited yield potential $\left(\mathrm{Y}_{\mathrm{wl}}\right)$, i.e. rainfed, but without nutrient, pest or disease limitations, also referred to as attainable yield (Lobell et al., 2009). For $Y_{\mathrm{ns}}$ simulation, we used typical farmers' management, i.e. automated irrigation supply of $20 \mathrm{~mm}$ of water 


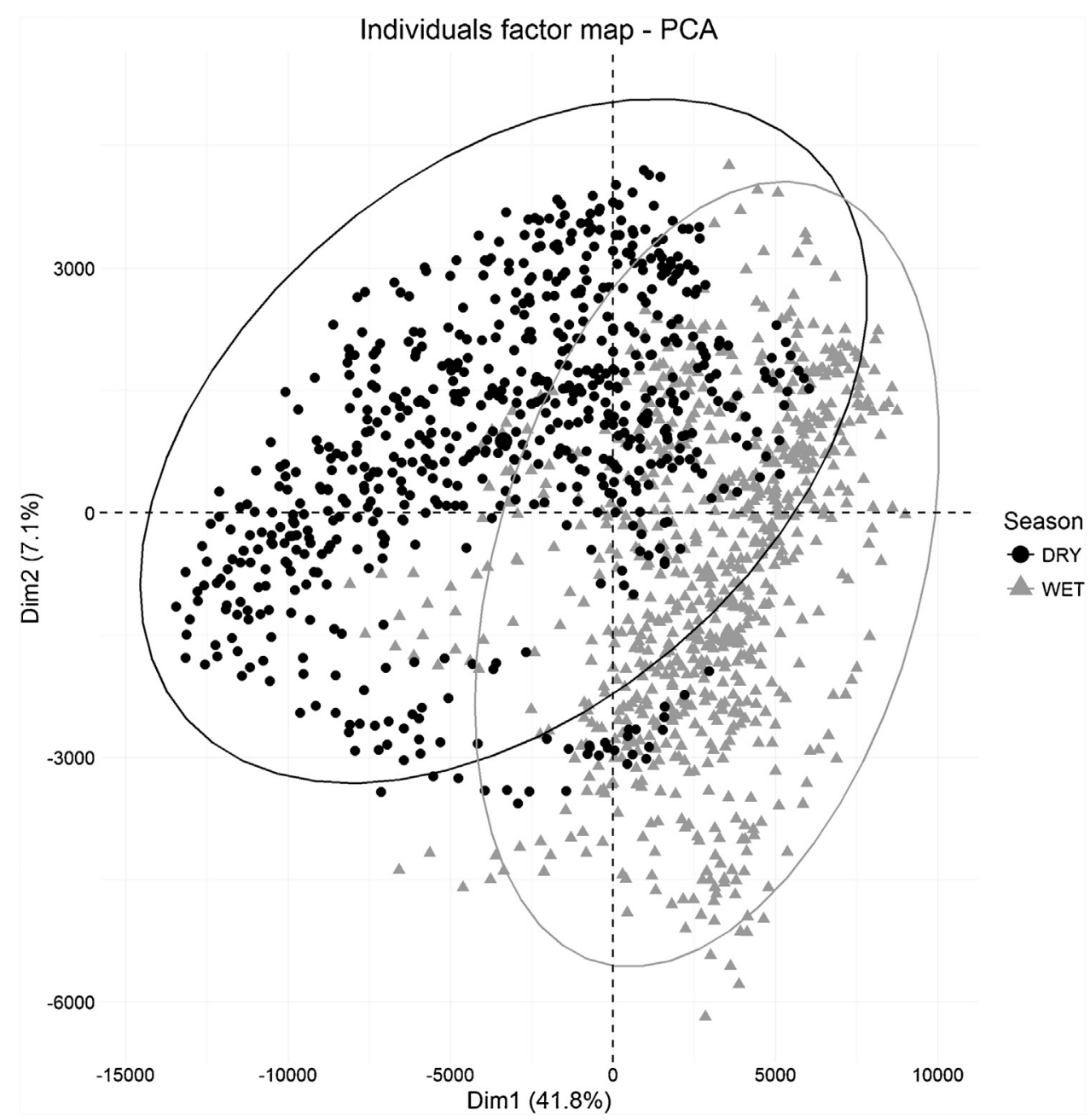

Fig. 6. Principal component analysis (PCA) based on all simulated yields for cultivars Pérola and BRS Radiante for the WET (grey full triangle) and DRY (black full circle) seasons. The ellipses represent $95 \%$ of confidence interval.

A

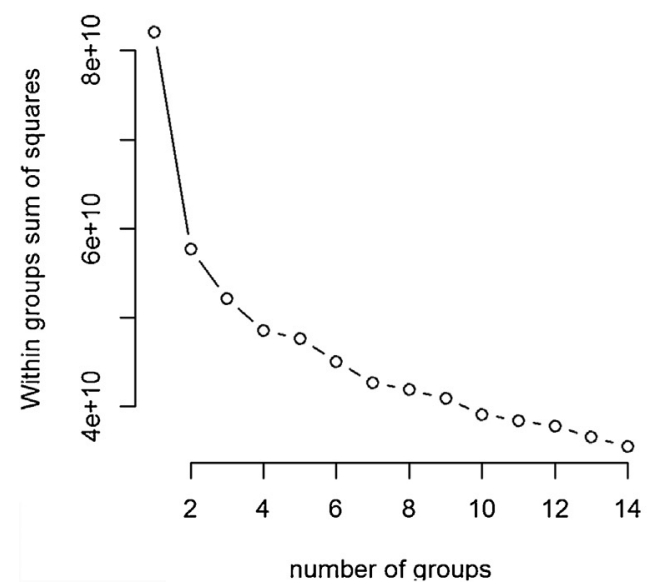

B

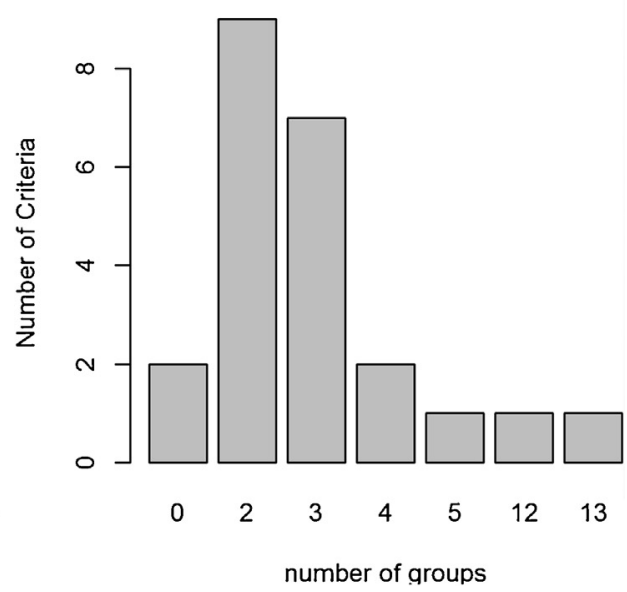

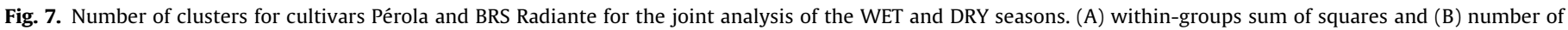
groups suggested based on 30 different criteria (Charrad et al., 2014).

when the moisture content of the top $30 \mathrm{~cm}$ of soil fell below $50 \%$ of the field capacity. Maximum rooting depth was set at 60, 40 and $40 \mathrm{~cm}$ for Oxisols, Ultisols and Inceptisols, respectively, based on soil samples in the calibration trials.

\subsubsection{Drought impact on yield}

The drought impact on yield was quantified by the relative water stress impact (RWSI), evaluated by expressing simulated attainable yield $\left(\mathrm{Y}_{\mathrm{wl}}\right)$ as a fraction of simulated yield with no water limitation 


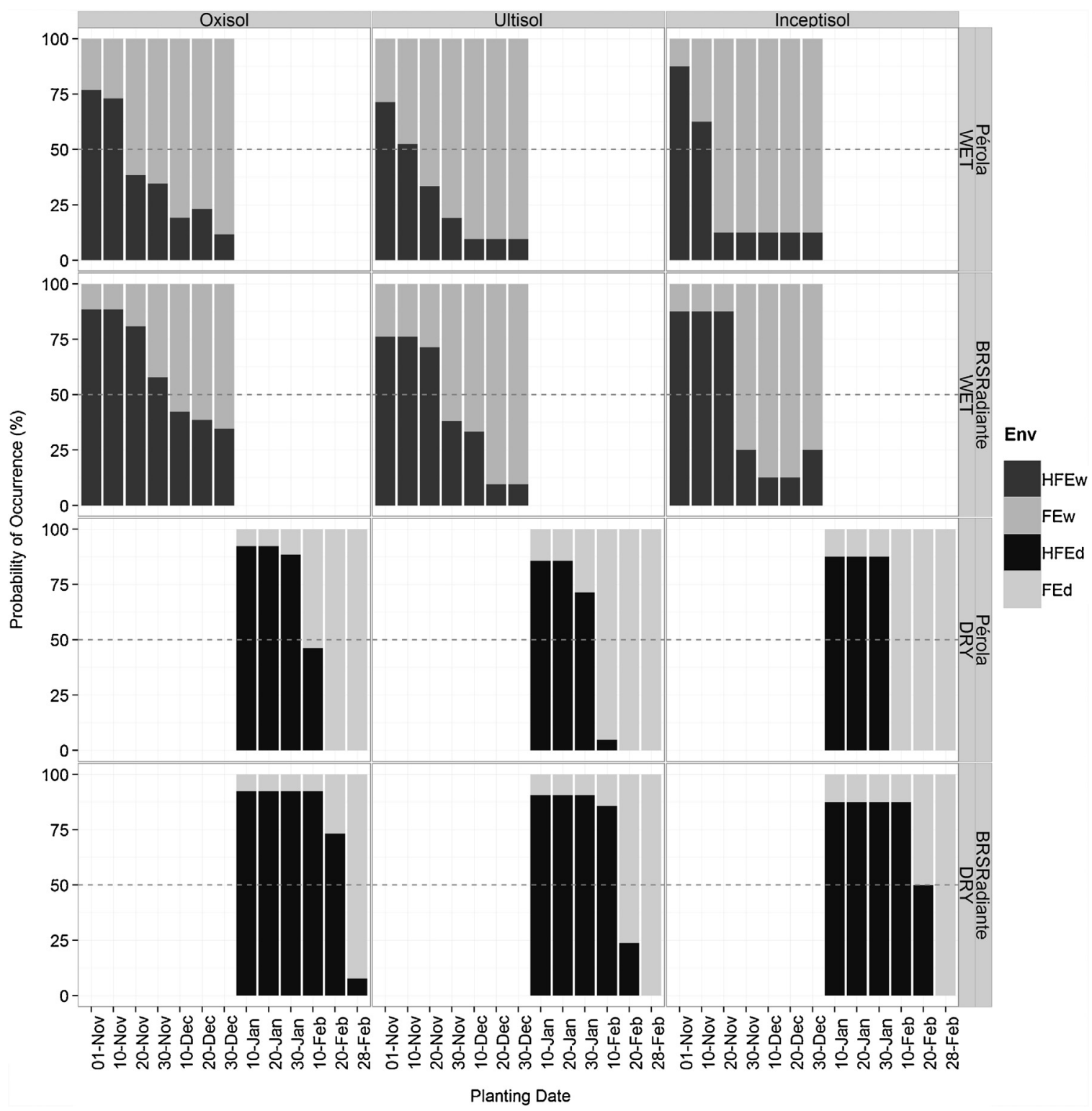

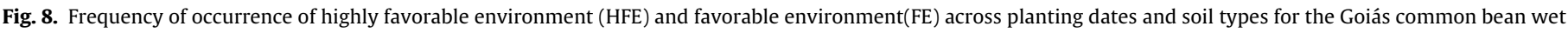
and dry target population of environments (TPEs).

$\left(\mathrm{Y}_{\mathrm{ns}}\right)$ (Eq. (1)), and a water stress impact (WSI) value was computed as the difference between $Y_{n s}$ and $Y_{w l}$ (Eq. (2)).

$$
\begin{aligned}
& \text { RWSI }=\frac{\left(Y_{\mathrm{ns}}-\mathrm{Y}_{\mathrm{wl}}\right)}{\mathrm{Y}_{\mathrm{ns}}} * 100 \\
& W S I=\left(\mathrm{Y}_{\mathrm{ns}}-\mathrm{Y}_{\mathrm{wl}}\right)
\end{aligned}
$$

\subsubsection{Determination of environment groups}

We used attainable (water and radiation-limited, $\mathrm{Y}_{\mathrm{wl}}$ ) yield to identify environment groups in the rainfed TPEs. To that aim, we used an agglomerative hierarchical clustering method (Williams, 1976) considering all individual (i.e. year, planting date, location and soil type) simulated yield $\left(\mathrm{Y}_{\mathrm{wl}}\right)$ values as inputs to the classification. The procedure used the squared Euclidean distance as the dissimilarity measure, and the incremental sum of squares as the fusion criterion (Ward, 1963). The number of environment groups was defined following Charrad et al. (2014) and Heinemann et al. (2015), whereby statistical and expert criteria are taken into account in the classification. As a robustness check to confirm that the two rainfed seasons are indeed two TPEs, we first clustered sim- ulations of both (wet and dry) seasons jointly, and then, in order to discriminate environments within each season, we performed clustering individually for each season.

\subsubsection{Typology of stress patterns}

For each environment group within the common bean rainfed TPEs, the main drought patterns were then determined using the temporal variation of five-days running average ratio of the water stress index (WSPD), calculated as the ratio of actual to demand transpiration, which acts in the model as a daily photosynthesis reduction factor. The simulated drought stress patterns were obtained by clustering the phenological sequence patterns of WSPD separately for each TPE and environment group (as determined above), following the same classification method as for the determination of environment groups (above). Following Chenu et al. (2011) and Heinemann et al. (2015), only values of WSPD during the period 20 days after planting to physiological maturation (R7) were used. This reduced potential errors from large temporal variation in WSPD during crop establishment and in the few common bean grains still growing after physiological maturity. All statisti- 

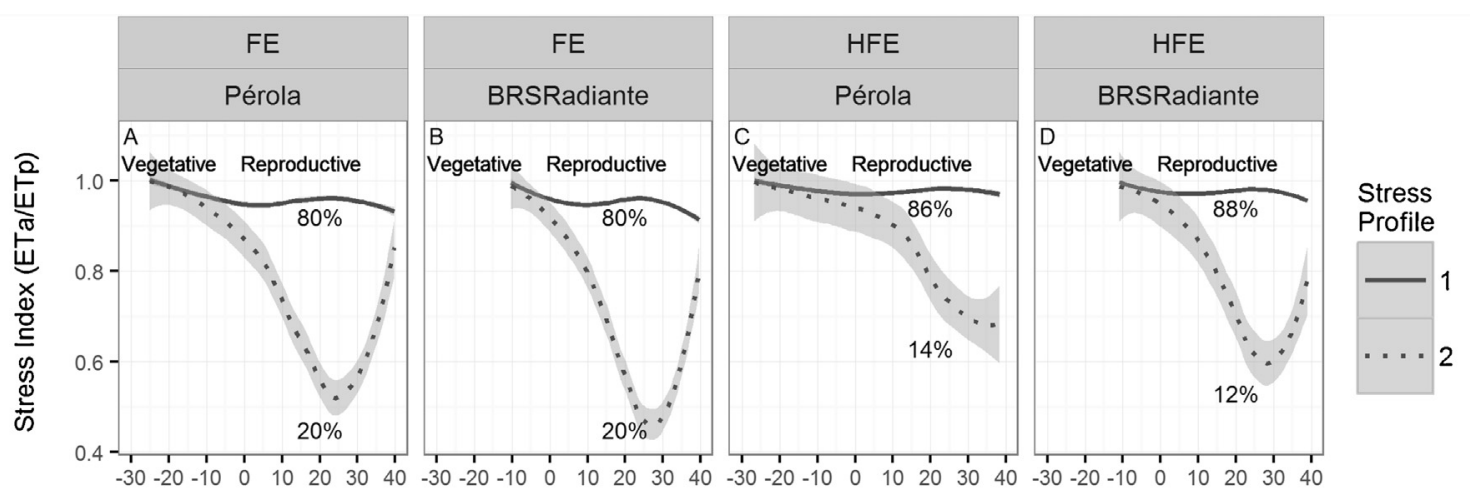

Days pre and post flowering from sowing
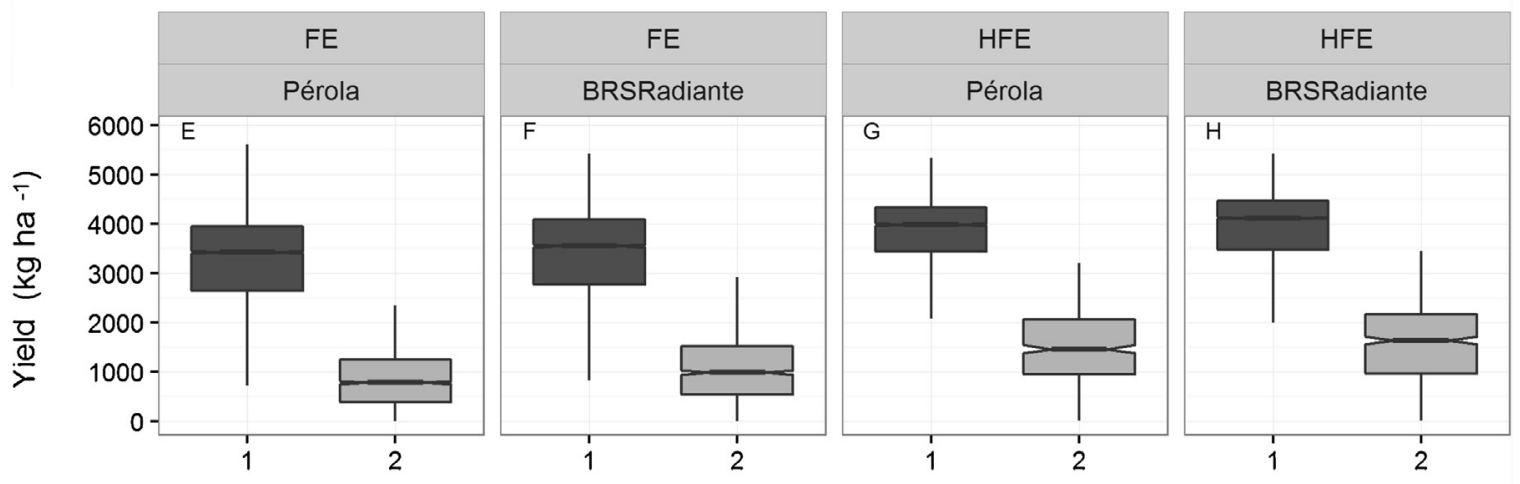

Stress Patterns

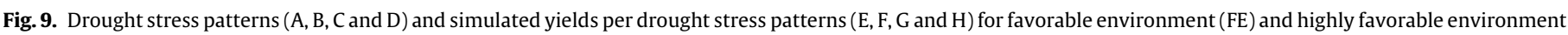

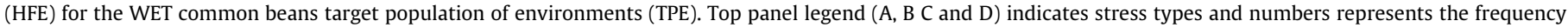

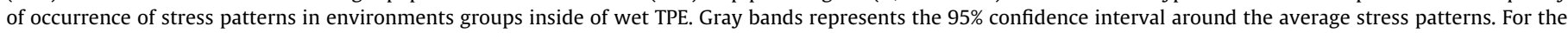

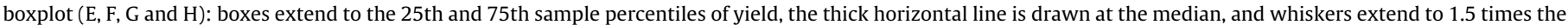
interquartile range. Stress Profile Legend: 1 -drought free profile; 2 -reproductive terminal drought stress (A, B, C and D).

cal analyses were performed using the base, stats and FactoMineR packages of the R software (R Core Team 2015).

\section{Results}

\subsection{Crop model skill}

The cultivar coefficient values parameterized and evaluated are given in Supplementary Table S4. The CSM-CROPGRO-DRY BEAN crop model showed good performance for predicting common bean phenology for both cultivars, Pérola and Radiante (Supplementary Fig. S1). Both cultivars also showed an acceptable agreement for simulating the total dry matter at flowering (RMSE was 347 and $188 \mathrm{~kg} \mathrm{ha}^{-1}$, Supplementary Fig. S1B, E for Pérola and Radiante). The crop model failed to capture the variation of total pod dry matter in the experiments for both cultivars for the parameterization and evaluation process (Supplementary Fig. S1 and S2C, F). Grain yield parameterization for both cultivars, Pérola and Radiante, showed a good performance (RMSE was 247 and 295; MAE was 224 and $272 \mathrm{~kg} \mathrm{ha}^{-1}$, Fig. 2A, B). It was somewhat reassuring, however, that for parameterization, all data fell within the confidence intervals derived from observed data ( $\alpha=95 \%)$. In the parameterization experiments, the crop model also captured well the seasonal variation in dry weight dynamics by organ and leaf area index (Supplementary Figs. S2 and S3).

As expected, for the EVAL1 (evaluation) dataset (Supplementary Fig. S4), the differences between model simulations and observations for phenology were large as compared to the parameterization dataset (PGE) for both cultivars. In general, Radiante simulations of phenology and the dynamic of growth variables were closer to observations than those of Pérola (Supplementary Figs. S3 and S4). In particular, simulated growth variables for Radiante showed less variation than observations, possibly highlighting misrepresentations or missing aspects in the crop model. For yield evaluation (EVAL2 data set, Fig. 2), overestimation was seen mainly for cultivar Radiante. Although the experiments were carried out to minimize biotic stress, sowing dates before May and after middle of July suffered from whitefly and excess rain during the grain filling phase. In spite of this, yield data fell within the confidence intervals derived from observed data ( $\alpha=95 \%)$ (Fig. 2C and D).

The CSM-CROPGRO-DRY BEAN crop model also captured well the seasonal variation in total dry matter dynamics and LAI under moderate drought (Fig. 3A, DRO data set at Table 1), although we observed a trend for the onset of drought impact to occur later for simulations than for measured values. For this drought level, the crop model also captured well the soil water content dynamics for layers $0-10,10-20,20-30$ and $30-40 \mathrm{~cm}$ (Fig. 4). For severe drought, the crop model failed to reproduce the dynamics of total dry matter and leaf area index (Fig. 3B) as well as of observed soil water content (Fig. 4). At the beginning of the growth cycle, the onset of drought occurred much later in the model as compared to the observations, and the impact on LAI was underestimated. Since the model performed well under moderate drought, we deem it appropriate for the work herein presented, as severe drought rarely occurs in the rainfed TPEs.

Simulated yield was also evaluated based on the observed yield from the multi-environment experiments (METs) from common bean breeding program (MET dataset, Table 1 ). Although we note 

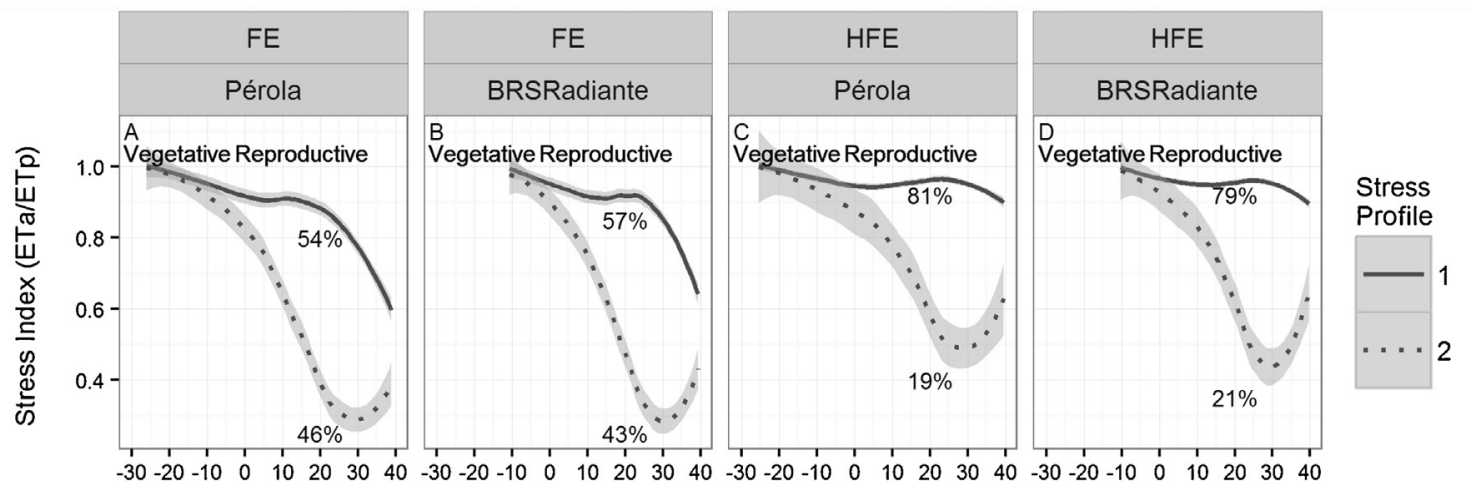

Days pre and post flowering from sowing
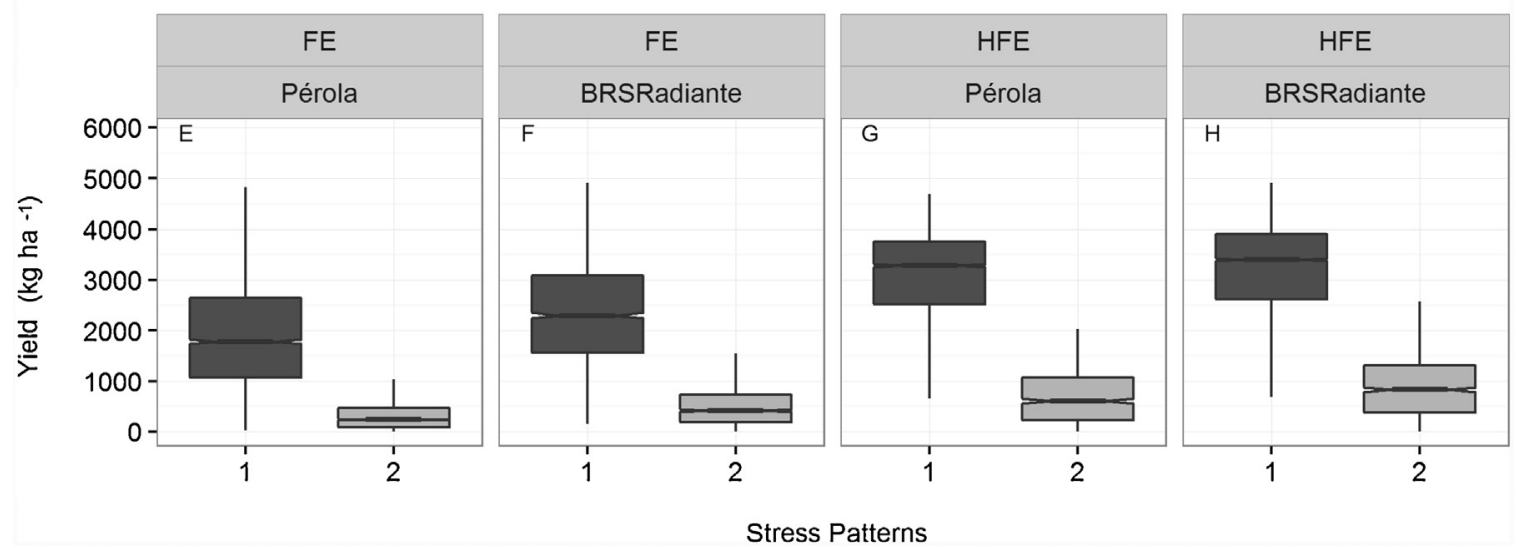

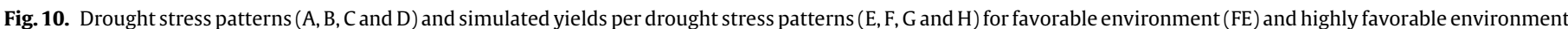

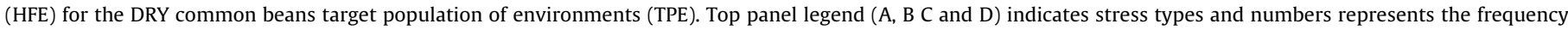

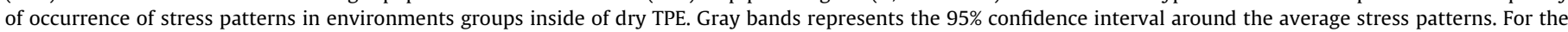

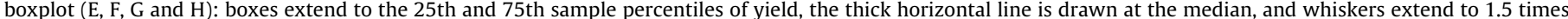

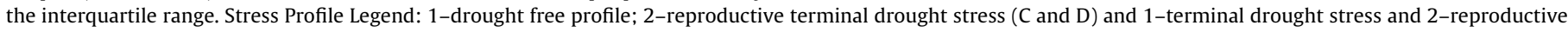
terminal drought stress (A and $\mathrm{B}$ ).

large variation across replicates in the observations, the results indicated relatively good model performance, with most simulations being within the confidence interval for both cultivars (Fig. 2E, F). The RMSE (MAE) for cultivars Radiante and Pérola were 404 (328) and 322 (319) $\mathrm{kg} \mathrm{ha}^{-1}$, respectively.

\subsection{Drought quantification}

Considering all sowing dates and soil types in the rainfed wet TPE, the median and mean relative water stress impact (RWSI) was less than $13 \%$ and $24 \%$ for both cultivars (Fig. 5A). Growing a short duration cultivar, Radiante, in this TPE reduces the drought impact on yield: the best and worst sowing date is higher for longer cycle cultivar Pérola (17.7\%) than for the earlier cycle cultivar Radiante (14.1\%) (Fig. 5C-D, vertical lines), primarily because the short duration cultivar escapes terminal drought. Using a risk analysis (Fig. 5B), however, we found that the early maturing cultivar was in advantage only when the water stress impact (WSI) on yield was larger than $1000 \mathrm{~kg} \mathrm{ha}^{-1}$. Based on these results, drought should not be considered the main constraint for this TPE. Moreover, for cultivar Pérola, sowing date towards the beginning of the sowing window (01-Nov) (Fig. 5C) and for Radiante sowing date at 10-Nov (Fig. 5D) minimize the water stress impact (WSI) on yield, indicating that appropriately selected sowing date can decrease the drought effects on yield.

In contrast, for the rainfed dry TPE, the median and average of RWSI were 50\% (31.3\%) and 48.3\% (36.7\%) for the Pérola (Radiante) cultivar, respectively (Fig. 5E). The risk analysis (Fig. 5F) indicated that the earlier cultivar always showed an advantage in minimizing drought impacts on yield in this TPE. Early sowing dates for both cultivars (Fig. 5G-H) minimized drought impacts on yield, again with the shorter duration cultivar (Radiante) being less sensitive due to its ability to escape drought (Fig. 5G and H, vertical lines).

\subsection{Environment characterization}

Environments (per historical year) as used in this paper were created by 26 weather stations ( 32 year of daily data for each station) within the region, three soils, and 13 sowing dates (wet and dry seasons). The difference between these two seasons, based on genotype performance (i.e. simulated yield) for both cultivars (Radiante and Pérola), is given in Fig. 6. For the wet season, the greatest variation was found in the $y$-axis (dimension 2), whereas for the dry season it was in the $x$-axis (dimension 1 ). This result confirmed that these seasons can be considered distinct Target Populations of Environments (TPEs). Overlap between the two TPEs happened probably due to similar growth conditions in specific years and sites. The number of clusters suggested by two different statistical analyses, within-groups sum of squares (Fig. 7A) and number of criteria (Charrad et al., 2014; Fig. 7B) indicated that the split is either at 2 or more groups. Also, simulated bean yield time series for both cultivars (Supplementary Fig. S5A-D) shows the difference between TPEs, thus confirming that the two rainfed seasons are two sets of distinct environments for breeding or TPEs. The wet TPE, as already expected, showed higher simulated yields for both cultivars than the dry TPE (Supplementary Fig. S5). Thus, our 
numerical analyses support the more empirical understanding of Embrapa's common bean breeders that the wet and dry seasons are indeed distinct TPEs.

\subsubsection{Wet TPE}

Two environment groups were identified in the Wet TPE based on cluster analyze on simulated yields: highly favorable environment (HFEw, 44\% occurrence in the Wet TPE) and favorable environment (FEw, 56\% occurrence in the Wet TPE). The highly favorable environment (HFEw) showed the highest yields (mean simulated yield $=3655 \mathrm{~kg} \mathrm{ha}^{-1}$, considering both cultivars), the highest annual precipitation (1448 $\mathrm{mm}_{\text {year }}{ }^{-1}$ ), and the lowest annual temperature amplitude and annual maximum, mean and minimum, temperatures $\left(1.6,28.3,22.5\right.$, and $\left.16.7^{\circ} \mathrm{C}\right)$. This environment is characterized by early sowing dates (between 01-Nov to 20 -Nov) (Fig. 8), the prevalence of cultivar Radiante (61\%) (Fig. 8), and the predominance of Oxisol soils (55\%). In this environment, the yield average and standard deviation for Pérola and Radiante were $3593( \pm 1002)$ and $3696( \pm 1027) \mathrm{kg} \mathrm{ha}^{-1}$, respectively. The favorable environment (FEw) showed lower yields, with an average simulated yield and standard deviation considering both cultivars of 2870 and $1274 \mathrm{~kg} \mathrm{ha}^{-1}$. In contrast to the HFEw, in this environment annual precipitation is relatively low ( $\left.1416 \mathrm{~mm} \mathrm{year}^{-1}\right)$, while annual temperature amplitude and annual maximum, mean and minimum, temperatures are relatively high $\left(1.8^{\circ} \mathrm{C}, 29.0^{\circ} \mathrm{C}\right.$, $23.2^{\circ} \mathrm{C}$, and $17.3^{\circ} \mathrm{C}$ ). FEw also showed a tendency towards late (i.e. after 10-Dec) sowing dates (Fig. 8), a predominance of the cultivar Pérola (58\%), and the predominance of two soil types, Ultisol (42\% occurrence in this TPE) and Oxisols (41\%). In this environment, the yield average and standard deviation for Pérola and Radiante were 2815 ( \pm 1279$)$ and $2947( \pm 1263) \mathrm{kg} \mathrm{ha}^{-1}$.

\subsubsection{Dry TPE}

Two environment groups were also identified in the common bean Dry TPE based on cluster analysis on simulated yields: highly favorable environment (HFEd, 58\% occurrence in the Dry TPE) and less favorable environment (FEd, $42 \%$ occurrence in the Dry TPE). For HFEd, the annual precipitation was $1451 \mathrm{~mm}^{-1} \mathrm{yr}^{-1}$, while annual maximum, mean and minimum, temperatures were 28.5, 22.8 , and $16.8^{\circ} \mathrm{C}$. The highly favorable environment (HFEd) showed overall average simulated yield and standard deviation of 2781 and $1202 \mathrm{~kg} \mathrm{ha}^{-1}$. The occurrence of HFEd is mainly conditioned by early sowing dates (10/01 to 30/01) (Fig. 8), and the presence of the short duration cultivar Radiante (60\% occurrence) grown in Oxisols (52\% of occurrences).The flowering date in this environment is, on average, 1 day earlier than HFEw. In this environment, the yield average and standard deviation for Pérola and Radiante were $2697( \pm 1211)$ and $2838( \pm 1192) \mathrm{kg} \mathrm{ha}^{-1}$, respectively.

The favorable environment (FEd) showed lower yields with average simulated yield and standard deviation considering both cultivars of 1356 and $1152 \mathrm{~kg} \mathrm{ha}^{-1}$. In this environment annual precipitation is lower than that of HFEd ( $1400 \mathrm{~mm}$ year $^{-1}$ ), while annual maximum, mean and minimum temperatures were higher $\left(28.9^{\circ} \mathrm{C} ; 23.1^{\circ} \mathrm{C}, 17.2^{\circ} \mathrm{C}\right)$. Contrary to what was observed for HFEd, the occurrence of FEd is conditioned by late planting dates (after 20/02) (Fig. 8), and the presence of cultivar Pérola (63\% occurrence) grown in (44\%) Ultisol and Oxisols (41\%). In this environment, the yield average and standard deviation for Pérola and Radiante were $1201( \pm 1100)$ and $1623( \pm 1190) \mathrm{kg} \mathrm{ha}^{-1}$.

\subsection{Major water-stress patterns}

\subsubsection{Wet TPE}

The major water-stress patterns were identified based on the temporal variation of five-days running average ratios of the water stress index (WSPD - ratio of actual to demand transpiration, see
Section 2.4.4 - Typology of stress patterns), via cluster analysis of the wet TPE environment groups (i.e. HFEw and FEw). Two predominant stress patterns were identified for the highly favorable environment (HFEw) (Fig. 9C, D) for both Pérola and Radiante, designated drought stress-free [1] and terminal reproductive-drought stress [2]. For both cultivars, the most frequent pattern ( 86 and $88 \%$ of frequency of occurrence for Pérola and Radiante, respectively) was stress-free [1] (Fig. 9C, D). Stress-free conditions are responsible for the highest simulated yields (Fig. 9G, H) with very similar yields for both Pérola and Radiante cultivars (mean $3841 \pm 692$ for Pérola and $3923 \pm 760 \mathrm{~kg} \mathrm{ha}^{-1}$ for Radiante). Terminal reproductive drought stress [2], for which onset occurs at 15 and 10 days prior to flowering with intensity increasing until the end of pod filling, occurred less frequently (14 and $12 \%$, for Pérola and Radiante). Terminal-reproductive stress caused a yield reduction of 38 and $40 \%$ for Pérola and Radiante with respect to stress-free conditions [1]. For terminal reproductive drought stress [2], the earlier cultivar, Radiante, showed higher yields. The average and standard deviation of flowering date for drought stress-free [1] and terminal reproductive drought stress [2] were $46( \pm 1.77)$ and $47( \pm 2.98)$ (Pérola) and $31( \pm 1.28)$ and 31 ( \pm 1.99$)$ (Radiante) DAS, respectively.

The seasonal variations in key meteorological variables, i.e., five days running accumulated rainfall, mean daily maximum and minimum temperature and mean daily solar radiation by crop cycle for both stress patterns are presented in Fig. 11. For stress-free conditions [1] 5-days accumulated rainfall increases from the vegetative to 10 days after flowering, followed by a decrease until physiological maturity. For conditions of terminal reproductive drought stress[2], there was a decrease in rainfall from 20 days before flowering until 15 days after flowering followed by another increase (Fig. 11C and D). Maximum temperature is lower for stress-free conditions (Fig. 11G and H). Solar radiation is higher for terminal reproductive drought stress[2] due to lower rainfall amount and less cloud cover for this stress condition (Fig. $11 \mathrm{~K}$ and $\mathrm{L}$ ).

In the favorable environment (FEw), the most frequent pattern was also drought stress-free [1], which occurred $80 \%$ of the time for both cultivars Pérola and Radiante (Fig. 9A, B). This pattern showed the highest simulated yields in the environment, and little variation across cultivars. The terminal reproductive-drought stress [2], which occurred $20 \%$ of the time for both Pérola and Radiante and had its highest intensity during the pod filling stage, reduced yields by 74 and $68 \%$ in relation to the stress-free pattern [1] (Fig. 9E, F). Similar flowering dates were found in both stress patterns in FEw as compared to HFEw. The main difference between drought stressfree [1] and terminal reproductive drought stress [2] in FEw is that for terminal reproductive stress, rainfall decreases (Fig. 11A and B) and maximum temperature increases (Fig. 11E and F), beginning 20 days after flowering, whereas for stress-free [1] there is an increase in rainfall and little or no increase in maximum temperature.

\subsubsection{Dry TPE}

The major water-stress patterns were identified based on WSPD (ratio of actual to demand transpiration) cluster analyze on Dry environment groups (HFEd and FEd). Two predominant stress patterns were identified for the highly favorable environment (HFEd) (Fig. 10C, D) for both cultivars, Pérola and Radiante, designated as drought stress-free [1] and terminal-reproductive drought stress [2]. For both cultivars, the most frequent pattern was stress-free [1], occurring 81 and $79 \%$ of the time for Pérola and Radiante, respectively (Fig. 10C, D). This pattern is responsible for the highest simulated yields (Fig. 10G, H), with a mean of $3078( \pm 886)$ and 3225 $( \pm 855) \mathrm{kg} \mathrm{ha}^{-1}$ for Pérola and Radiante. Terminal-reproductive drought stress [2] occurred in only 19\% (21\%) of the simulations for cultivar Pérola (Radiante). The onset of this stress occurs at 20 (Pérola) and 10 (Radiante) days before flowering with intensity 


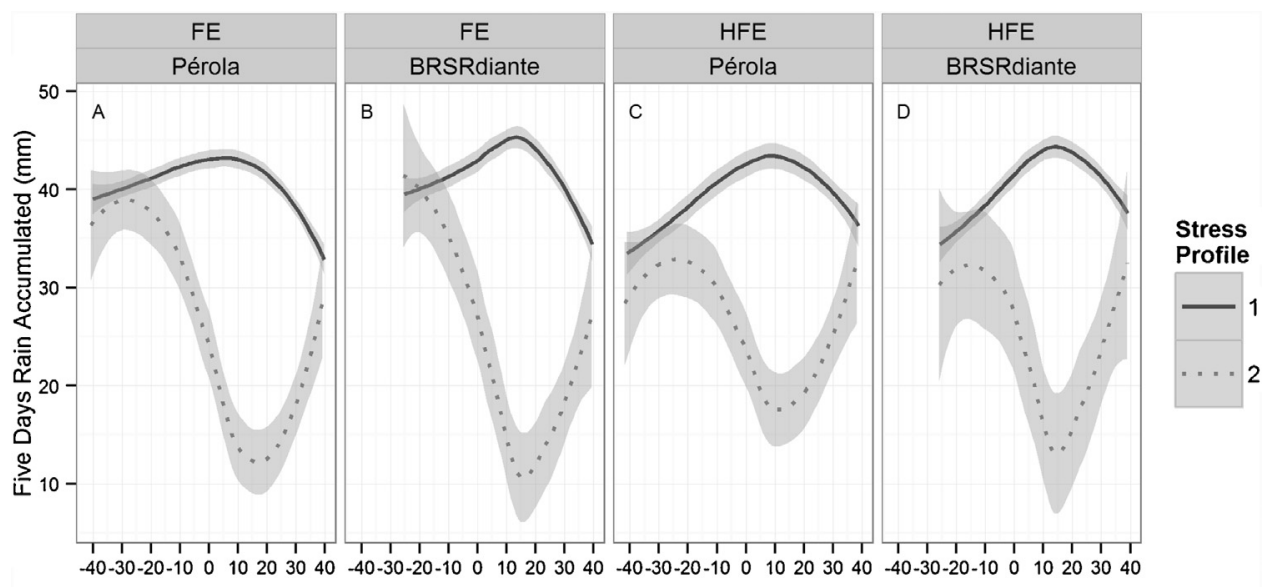

Days pre and post flowering from sowing

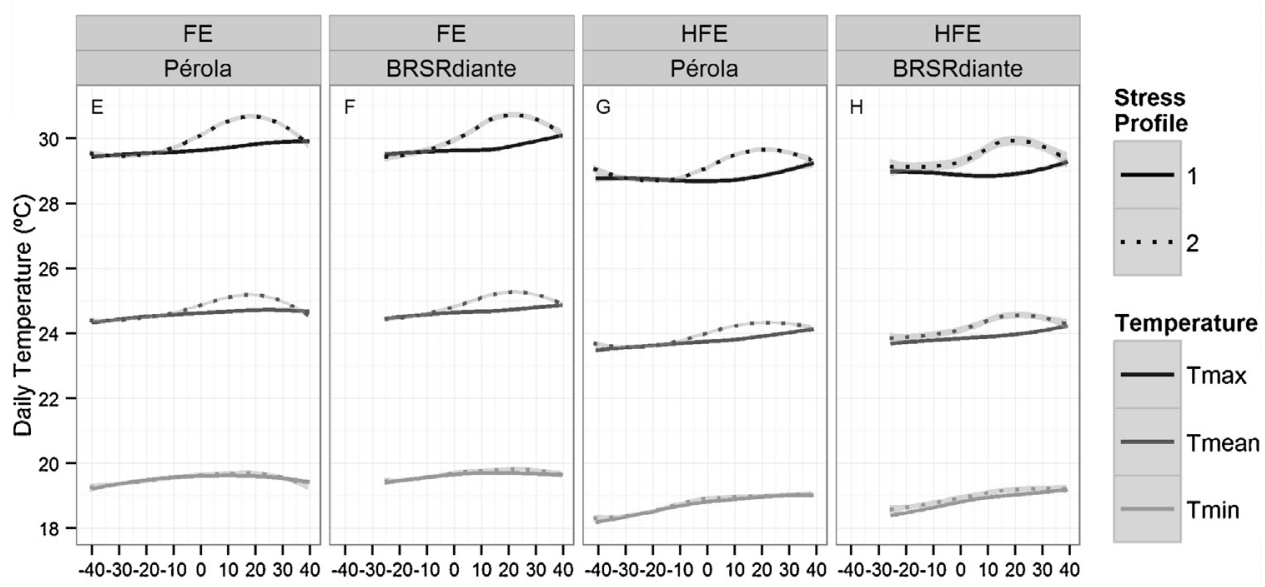

Days pre and post flowering from sowing

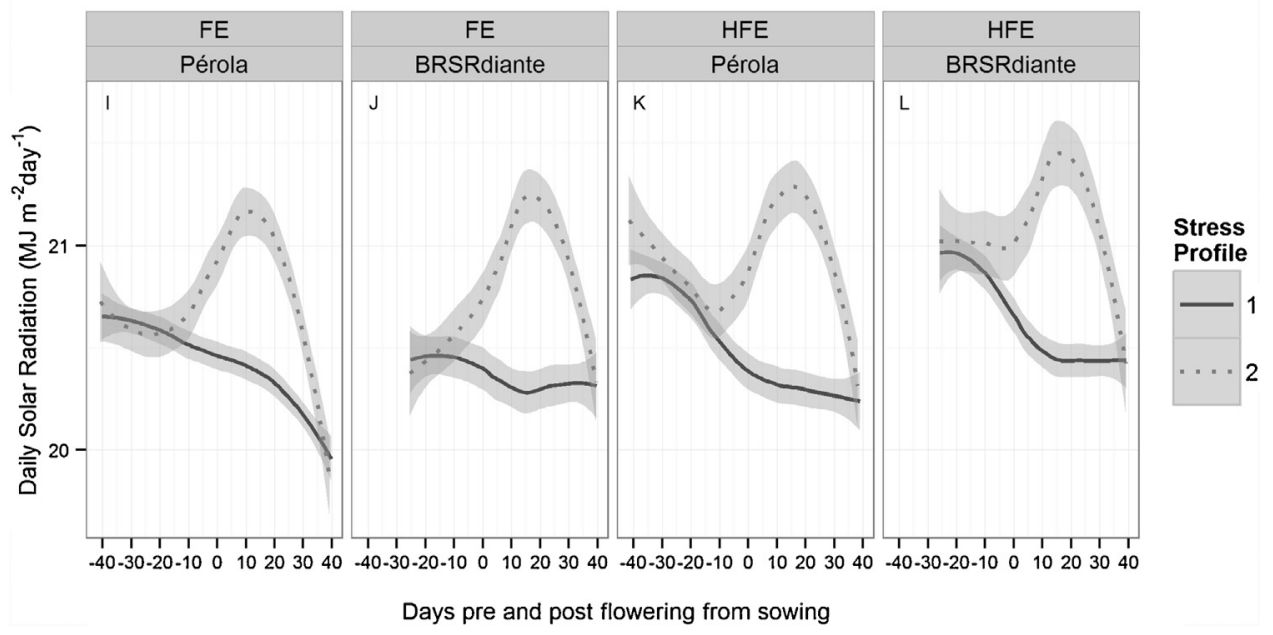

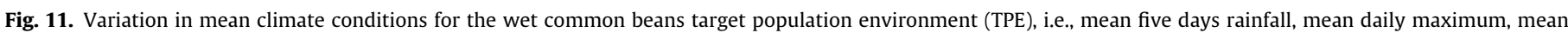

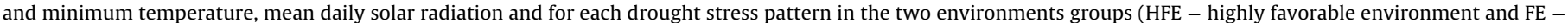
favorable environment). For stress profile legend, see Fig. 9.

increasing until the end of pod filling, causing a yield reduction of 78 and $72 \%$ for Pérola and Radiante with respect to stressfree conditions [1]. Cultivar Radiante, as in HFEw (see above), presented the highest yields. Weekly variations in meteorological variables are shown in Fig. 12. For stress-free conditions [1], the five days accumulated rainfall decreased starting 10 days after flowering and continued until physiological maturity for both culti- vars. For terminal-reproductive drought stress [2], rainfall started decreasing 20 days before flowering (Fig. 12C and D). Maximum and minimum temperatures are higher for terminal-reproductive drought stress [2], with a higher rate of increase in maximum temperature (Fig. $12 \mathrm{G}$ and $\mathrm{H}$ ). Solar radiation decreased from 21 to $17 \mathrm{MJ} \mathrm{day}^{-1}$ throughout the crop cycle (Fig. $12 \mathrm{~K}$ and L). 


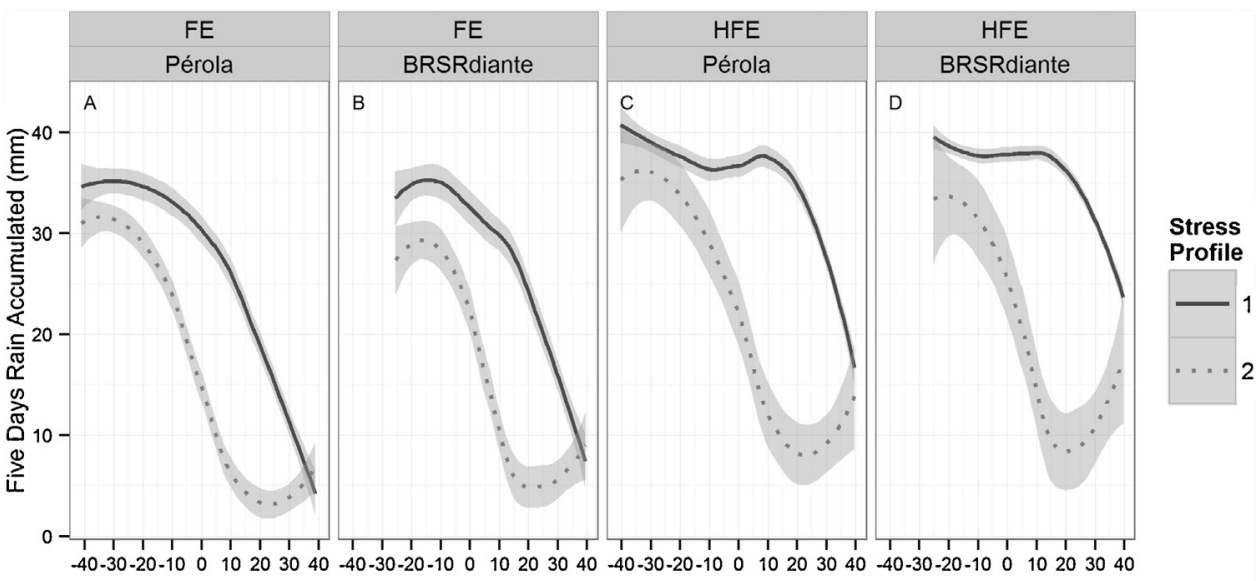

Days pre and post flowering from sowing

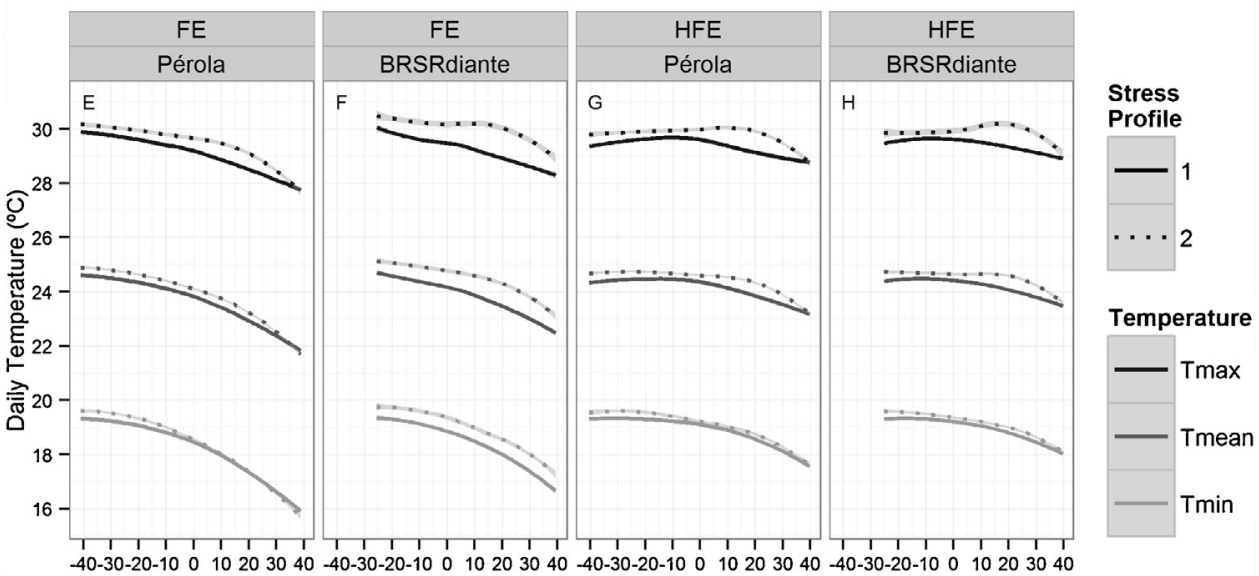

Days pre and post flowering from sowing

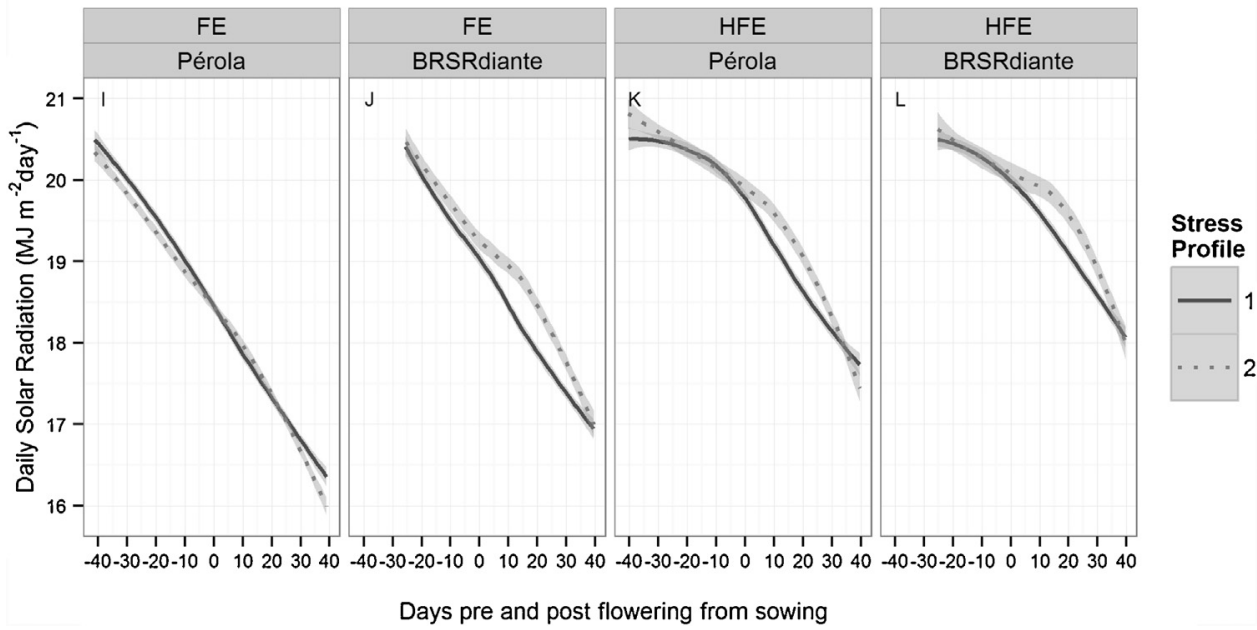

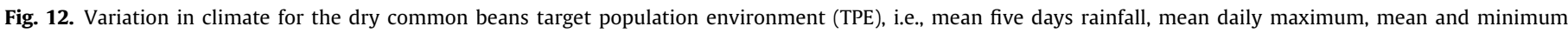

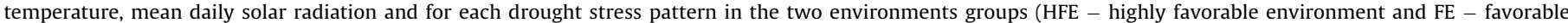
environment). For stress profile legend, see Fig. 10.

In the favorable environment (FEd), two predominate patterns were also found, for both cultivars, terminal drought stress [1] and reproductive terminal drought stress [2]. Terminal drought stress [1] represented $54 \%$ and $57 \%$ of the frequency of occurrences for Pérola and Radiante (Fig. 10A and B). Cultivar Radiante showed higher simulated yields $\left(2314 \pm 969 \mathrm{~kg} \mathrm{ha}^{-1}\right)$ than cultivar Pérola $\left(1900 \pm 995 \mathrm{~kg} \mathrm{ha}^{-1}\right)$ for this drought stress pattern (Fig. 10E, F).
The terminal reproductive drought stress [2], which presented a frequency of 46 and $43 \%$ for Pérola and Radiante, had its highest intensity during the pod filling stage, with yields $84 \%$ (Pérola) and $78 \%$ (Radiante) lower in relation to the terminal drought stress pattern [1] (Fig. 10E and F). Decreased rainfall 20 days before flowering was observed for the longer cycle cultivar, Pérola, for both stress patterns. For the earlier cultivar, Radiante, the rainfall decrease 
started to occur 10 days before flowering for both stress patterns (Fig. 12A and B). The minimum temperature and solar radiation decrease rates are higher for this environment group than for the HFEd (Fig. 12E, F, I, J).

\section{Discussion}

\subsection{Importance of drought across environment groups}

The results obtained in this study showed that drought is not the main constraint for the wet TPE (Fig. 9A, B, C and D). This result agrees with the results obtained by Beebe et al. (2011), who used a crop suitability model and showed that central Brazil is highly suitable for growing common bean. For both environment groups at wet TPE, HFEw and FEw, and the two cultivars Pérola and Radiante, there is a predominance of drought stress-free (86\% overall). According to Allen et al. (1998) and White et al. (1995) the water requirements for maximum production of a 60-120 day common bean crop vary from 300 to $500 \mathrm{~mm}$ depending on the environment demands, soil type and nutrition. For the drought stress-free [1] profiles in both the HFEw and FEw environments groups, the total seasonal precipitation for Pérola was 696 [HFEw] and 478 [FEw] mm, whereas for Radiante it was 589 [HFEw] and 382 [FEw] $\mathrm{mm}$, all of which are within or higher than the requirement for maximum production. For the wet TPE, drought stress is related with the increase of maximum temperature as shown in Fig. 11E, $\mathrm{F}, \mathrm{G}$ and $\mathrm{H}$. Our results also show that drought is a major limiting factor only for the FEd environment group in the dry TPE. In this TPE, appropriate choices of sowing date and cultivar are important factors to minimize drought stress. In particular, we highlight the importance of cultivars that can escape drought, as seen in the generally higher yields shown by cultivar Radiante (early flowering and early maturity for most drought stress situations). As the Goiás rainfed TPEs are characterized basically by small scale farmers and low input agriculture, the adoption of early cultivars should be weighted when considering the most relevant stress factors that act on these TPEs, not only drought. Early maturing cultivars, generally of determinate growth habit, e.g. Radiante, do not yield well in an intermittent drought environment. LAI may stop increasing at a relatively early stage due to the lack of nodes for producing additional leaves (White and Izquierdo, 1991), which in turn does not allow sustained recovery of reproductive growth following precipitation (Vandenberg and Nleya, 1999). On the other hand, indeterminate growth habit that flower in flushes, e.g. Pérola, resumes growth after flowering conditions improve (Beebe et al., 2011; RosalesSerna et al., 2004; Vilhordo et al., 1996). In addition, earlier cultivars are less efficient in fixing biological nitrogen during grain filling and require a high-tech management due to lower plasticity inherent to the genotype (Didonet, 2005).

\subsection{Implications of drought stress for the common bean breeding program}

Common bean in the Goiás State are cropped in three TPEs per year, here referred to as wet, dry and winter. The main focus of this study was on the rainfed TPEs: wet and dry. Breeding activities for common bean screening in early generation yield tests (nursery) consist of three phases, namely, progeny test (PT), test of preliminary lines (PL) and intermediate test (IT) (Melo, 2009). All phases are carried out in the winter Goiás TPE, in one site (Santo Antônio de Goiás, GO, latitude: -16.47 ; longitude: $-49.28 \mathrm{~W}$ ), under stressfree conditions (fully irrigated). The PT generally has from 30 to 200 lines and the target traits are yield, lodging, disease resistance and plant architecture. The best lines, about half of PT, go to PL, which has the same target traits as PT. Both PT and PL are per- formed every two years. All lines in PL are tested in a controlled environment for anthracnose, common bacterial disease and common mosaic necrotic virus. The best lines are selected for IT, which has yield, lodging, disease resistance and plant architecture as target traits. The best lines, generally 10-15 lines, are selected for the testing sites (or "multi environment trials" [METs]), where they are compared with 3-5 check genotypes. The fact that selection is done under well-watered conditions implies that cultivars may lack the plasticity needed to respond well under the stresses present in the wet and dry TPEs. While this is a potential caveat of the current breeding program strategy, our analyses suggest that as percentage production of the Goiás State (i.e. all three TPEs), drought stress conditions occur only in $14.4 \%$ (Pérola) and $14.9 \%$ (Radiante) of seasons (sites-by-years). As a fraction of the rainfed TPEs, drought conditions occur roughly in one fourth of the seasons (23.9\% for Pérola and $24.7 \%$ for Radiante). Results obtained in this study for both rainfed TPEs suggest that the choice of sowing date is more important than the choice of cultivar for drought risk management (Figs. 8-10) and are in agreement with Didonet (2005). Chenu (2014) who also showed that the source of yield variation arises primarily from the environment $(E)$, secondly from the $(G \times E)$ interactions and, finally, from the genotype $(G)$. Given the importance of developing germplasm that achieves high yields but also has enough plasticity so as to tolerate drought conditions occurring in particular areas or years, in the following section we suggest some potential avenues to improve the current breeding practice.

\subsection{Specific breeding strategies for the common bean TPES}

As already highlighted above, the common bean breeding program does not perform varietal selection in either of the Goiás rainfed TPEs, but just tests the genotypes selected in the winter TPE in these environments through the METs. Generally, only yield is recorded in METs. As yield is the result of many interacting processes, it is challenging to determine the events (abiotic or biotic) associated with yield reduction in the different environments. The common bean breeders deliberately do not perform screening in Goiás rainfed TPEs (wet and dry) due to a high probability of crop failure mainly due to high pressure of diseases (BGMV among others). Based on this argument, cultivars developed by this breeding program are not adapted for the Goiás rainfed TPEs. We also emphasize that the crop model applied in this study does not account for diseases. This study showed that drought stress occurs at a relatively low frequency in the wet TPE (both environment groups) as well as for the HFE in the dry TPE. However, under specific situations yield reductions associated with drought can be large, albeit localized. Specifically, we note large (>50\%) yield reductions in the north and north-east of the Goiás state in the dry TPE (Supplementary Fig. S6). Although a cost-benefit analysis would be needed to determine whether establishing drought-tailored selection is economically viable, the relatively low frequency of occurrence of drought would suggest that drought-tailoring may not be warranted.

In addition to drought, there may be additional stresses that could act to reduce both current and future bean production, which were not considered here because the model does not simulate adequately. Firstly, the direct and indirect injury effects of water logging that reduce yield primarily by causing roots to rot. Recent observations suggest that water logging injuries currently occur in the field (Lima et al., 2013; Thung and Rao, 1999; White and Izquierdo, 1991), being one of the reasons for farmers to grow bean in the dry TPE. Secondly, high day temperatures $\left(>30^{\circ} \mathrm{C}\right)$ or night temperatures $\left(>20^{\circ} \mathrm{C}\right)$ can reduce yields (Beebe et al., 2011; Porch, 2006; Prasad et al., 2003; Rainey and Griffiths, 2005), which the model does account for, but with undocumented accuracy on thresholds. Whilst in the present work maximum mean temperature only reaches $30^{\circ} \mathrm{C}$ in the FEw environment group at the end of 
the cycle, under warmer future conditions such as those projected by global climate models, heat stress may become an important limiting factor (e.g. Beebe et al., 2011). Finally, pests and diseases and their seasonal dynamics may also cause large yield reductions and merit specific selection strategies particularly at early breeding stages. Although only further analyses will reveal which stresses are the most critical and therefore the ones breeders should be selecting for, the vast yield differences that exist between the rainfed and winter TPEs suggest that the common bean breeding program should adapt their selection practices for the Goiás rainfed TPEs to select genotypes more suitable for these environments. It is expected that such a tailored strategy would decrease production risks in relation to the current selection for broad adaptation. We suggest further studies to include additional stresses of heat and disease in the wet and dry seasons, and weigh their importance in light of developing a robust breeding strategy for both current and future climates.

\section{Acknowledgements}

This work was supported by CGIAR Research Program on Climate Change, Agriculture and Food Security (CCAFS), sub project "A methodological development of an online tool for the identification of Target Population Environments: improving the predictions of agricultural production using crop models" and CNPq project 471827/2012-6 Universal 2012.

\section{Appendix A. Supplementary data}

Supplementary data associated with this article can be found, in the online version, at http://dx.doi.org/10.1016/j.agrformet.2016. 05.010 .

\section{References}

Alderman, P.D., Boote, K.J., Jones, J.W., Bhatia, V.S., 2015. Adapting the CSM-CROPGRO model for pigeonpea using sequential parameter estimation. Field Crop. Res. 181, 1-15, http://dx.doi.org/10.1016/j.fcr.2015.05.024.

Allen, R.G., Pereira, L.S., Raes, D., Smith, M., 1998. Crop Evapotranspiration: Guidelines for Computing Crop Water Requirements. FAO, Rome, Italy.

Araujo, S.S., Beebe, S., Crespi, M., 2015. Abiotic stress responses in legumes: strategies used to cope with environmental challenges. CRC Crit. Rev. Plant Sci. 34, 237-280, http://dx.doi.org/10.1080/07352689.2014.898450.

Assis, P.C.R., Stone, L.F., Medeiros, J.C., Madari, B.E., Oliveira, J.M., Wruck, F.J., 2015. Physical attributes of soil in integrated crop-livestock-forest systems. Rev. Brasil. Eng. Agric. Ambiental 19, 309-316, http://dx.doi.org/10.1590/18071929/agriambi.v19n4p, 309-316.

Barcelos, Q.L., Pinto, J.M.A., Vaillancourt, L.J., Souza, E.A., 2014. Characterization of Glomerella strains recovered from anthracnose lesions on common bean plants in Brazil. PLoS One 9, 1-15, http://dx.doi.org/10.1371/journal.pone.0100438.

Beebe, S., Ramírez, J., Jarvis, A., Rao, I.M., Mosquera, G., Bueno, J.M., Blair, M.W., 2011. Genetic improvement of common beans and the challenges of climate change. In: Yadav, S.S., Redden, R., Hatfield, J.L., Lotze-Campen, H., Hall, A. (Eds.), Crop Adaptation to Climate Change. Wiley-Blackwell, Oxford, UK, pp. 356-369.

Benedetti, M.M., Sparovek, G., Cooper, M., Curi, N., Carvalho Filho, A., 2008. Coverage and potential use of a soil profile database in Brazil. Rev. Bras. Cienc Solo 32, 2591-2600, http://dx.doi.org/10.1590/S0100-06832008000600036.

Chapman, S., 2008. Use of crop models to understand genotype $\mathrm{x}$ by environment interactions for drought in real-world and simulated plant breeding trials. Euphytica 161, 195-208, http://dx.doi.org/10.1007/s10681-007-9623-z.

Charrad, M., Ghazzali, N., Boiteaau, V., Niknafs, A., 2014. NbClust: an R Package for determining the relevant number of clusters in a data set. J. Stat. Software 61, $1-36$.

Chauhan, Y.S., Solomon, K.F., Rodriguez, D., 2013. Characterization of north-eastern Australian environments using APSIM for increasing rainfed maize production. Field Crop. Res 144, 245-255, http://dx.doi.org/10.1016/j.fcr.2013.01.018.

Chenu, K., Cooper, M., Hammer, G.L., Mathews, K.L., Dreccer, M.F., Chapman, S.C., 2011. Environment characterization as an aid to wheat improvement: interpreting genotype-environment interactions by modelling water-deficit patterns in North-Eastern Australia. J Exp. Bot 62, 1743-1755.

Chenu, K., 2014. Characterizing the crop environment: nature, significance and applications. In: Sadras, V.O., Calderini, D.F. (Eds.), Crop Physiology: Applications for Genetic Improvement and Agronomy. Academic Press, Boston, MA, pp. 321-348.
Comissão Técnica Sul-Brasileira de Feijão2010. Informações técnicas para o cultivo do feijão na região sul brasileira. Florianópolis. EPAGRI. 163 p.

Cooper, M., Stucker, R.E., DeLacy, I.H., Harch, B.D., 1997. Wheat breeding nurseries, target environments, and indirect selection for grain yield. Crop Sci 37. 1168-1176.

D’Afonseca D.S., Heinemann A.B., Silva S.C., Moraes A.C., 2012, Preenchimento de dados climáticos diários faltantes para os municípios do Estado de Rondônia na base de dados de clima da Embrapa Arroz e Feijão, Santo Antônio de Goiás, Brazil, Embrapa Arroz e Feijão.

D’Afonseca D.S., Heinemann A.B., Silva S.C., Moraes A.C., 2013, Preenchimento de dados climáticos diários faltantes para os municípios do Estado de Mato Grosso na base de dados de clima da Embrapa Arroz e Feijão, Santo Antônio de Goiás, Brazil: Embrapa Arroz e Feijão.

D’Afonseca DS, Heinemann AB, Silva SC, Moraes AC. 2013. Metodologia para o preenchimento de dados climáticos diários faltantes: uma aplicação para os municípios de Goiás a partir da base de dados de clima da Embrapa Arroz e Feijão. Santo Antônio de Goiás, Brazil: Embrapa Arroz e Feijão.

De Luque, J.J.R., Creamer, B., 2014. Major constraints and trends for common bean production and commercialization, establishing priorities for future research. Agron. Colomb. 32, 423-431

Didonet, A.D., 2005. Ecofisiologia e rendimento potencial do feijoeiro. In: Del Peloso, M.J., Melo, L.C. (Eds.), Potencial De Rendimento Da Cultura Do Feijoeiro Comum. Embrapa Arroz e Feijão, Santo Antônio de Goiás, Brazil, pp. 9-37.

Embrapa Arroz e Feijão, 2015. Dados de conjuntura da produção de feijão (Phaseolus vulgaris L.) no Brasil (1985-2013), URI: http://www.cnpaf. embrapa.br/socioeconomia/index.htm (acessed 12.05.15.).

FAOSTAT, Food and Agriculture Organization of the United Nations. FAOSTAT (Database). URI: http://data.fao.org/ref/262b79ca-279c-4517-93deee3b7c7cb553.html? version=1.0 (accessed July 06.07.15.).

Faria, L.C., Del Peloso, M.J., Costa, J.G.C., Rava, C.A., Carneiro, G.E.S., Soares, D.M., Cabrera Diaz, J.L., Sartorato, A., Faria, J.C., 2003. BRS Radiante - sugar common bean. Crop Breed. Applied Biotech. 3, 307-310.

Heinemann, A.B., Stone, L.F., 2015. Requirement of supplemental irrigation for dry season common bean in Goiás. Irrigation 1 (2), 57-66, http://dx.doi.org/10. 15809/irriga.2015v1n2.

Heinemann, A.B., Hoogenboom, G., Georgiev, G.A., Faria, R.T., Frizzone, J.A., 2000. Center pivot irrigation management optimization of dry beans in humid areas. Trans. ASAE 43, 1507-1516.

Heinemann, A.B., Hoogenboom, G., Faria, R.T., 2002. Determination of spatial water requirements at county and regional levels using crop models and GIS: an example for the State of Parana, Brazil. Agric. Water Manage 52, 177-196, http://dx.doi.org/10.1016/S0378-3774(01)00137-8.

Heinemann, A.B., Dingkuhn, M., Luquet, D., Combres, J.C., Chapman, S., 2008. Characterization of drought stress environments for upland rice and maize in central Brazil. Euphytica 162, 395-410.

Heinemann, A.B., Barrios-Perez, C., Ramirez-Villegas, J., Arango-Londono, D., Bonilla-Findji, O., Medeiros, J.C., Jarvis, A., 2015. Variation and impact of drought-stress patterns across upland rice target population of environments in Brazil. J. Exp. Bot. 66, 3625-3638, http://dx.doi.org/10.1093/jxb/erv126.

Hoogenboom, G., Jones, J.W., Boote, K.J., 1992. Modeling growth, development, and yield of grain legumes using SOYGRO, PNUTGRO, and BEANGRO: a review. Trans. ASAE 35, 2043-2056, http://dx.doi.org/10.13031/2013.28833.

IBGE. Instituto Brasileiro de Geografia e Estatística2015. Produção agrícola municipal: área plantada, área colhida, quantidade produzida e valor da produção da lavoura temporária. URI: http://www.sidra.ibge.gov.br/bda/ acervo/acervo9. $\mathrm{asp} ? \mathrm{e}=\mathrm{c} \& \mathrm{p}=\mathrm{PA} \& \mathrm{z}=\mathrm{t} \& \mathrm{o}=11$ (accessed 20.06.15.).

Informações técnicas para o cultivo do feijoeiro-comum na região central-Brasileira. 2012. Santo Antônio de Goiás, Brazil: Embrapa Arroz e Feijão.

Jones, J.W., Hoogenboom, G., Porter, C.H., Boote, K.J., Batchelor, W.D., Hunt, L.A., Wilkens, P.W., Singh, U., Gijsman, A.J., Ritchie, J.T., 2003. The DSSAT cropping system model. Eur. J. Agron 18, 235-265, http://dx.doi.org/10.1016/S11610301(02)00107-7.

Kelly, J.D., Cichy, K.A., 2013. Dry bean breeding and production technologies. In: Siddiq, M., Uebersax, M.A. (Eds.), Dry Beans and Pulses Production, Processing and Nutrition. Wiley-Blackwell, Oxford, UK, pp. 23-54.

Löffler, C.M., Wei, J., Fast, T., Gogerty, J., Langton, S., Bergman, M., Merrill, B. Cooper, M., 2005. Classification of maize environments using crop simulation and geographic information systems. Crop Sci. 45, 1708-1716, http://dx.doi. org/10.2135/cropsci2004.0370.

Lima Filho, A.F., Coelho Filho, M.A., Heinemann, A.B., 2013a. Calibration and evaluation of CROPGRO model for cowpea in Recôncavo of Bahia - Brazil. Rev. Bras. Eng. Agric. Ambiental 17, 1286-1293, http://dx.doi.org/10.1590/S141543662013001200006.

Lima Filho, A.F., Coelho Filho, M.A., Heinemann, A.B., 2013b. Determining the optimum sowing dates for cowpea based on CROPGRO model in Recôncavo of Bahia ?Brazil, Rev. Bras. Eng. Agric. Ambiental 17, 1294-1300, http://dx.doi. org/10.1590/S1415-43662013001200007.

Lima, L.K., Ramalho, M.A.P., Abreu, A.F.B., 2013. Selection of common bean inbred lines with tolerance to high moisture at harvest. Ciênc. Agrotecnol. 37, 152-158, http://dx.doi.org/10.1590/S1413-70542013000200006.

Lobell, D.B., Cassman, K.G., Field, C.B., 2009. Crop yield gaps: their importance, magnitudes, and causes. Annu. Rev. Environ. Resour. 34, 179-204, http://dx. doi.org/10.1146/annurev.environ.041008.093740.

Müller, B.S.F., Sakamoto, T., Silveira, R.D.D., et al., 2014. Differentially expressed genes during flowering and grain filling in common bean (Phaseolus vulgaris) 
grown under drought stress conditions. Plant Mol. Biol. Rep. 32, 438-451, http://dx.doi.org/10.1007/s11105-013-0651-7.

Melo, L.C., Costa, J.G.C., Pereira, H.S., 2012. Common bean cultivar BRS Ametista with large Carioca grains and disease resistance. Crop Breed. Applied Biotech 12, 293-296, http://dx.doi.org/10.1590/S1984-70332012000400011.

Melo L.C. 2009. Procedimentos para condução de experimentos de Valor de Cultivo e Uso em feijoeiro comum. Santo Antônio de Goiás, Brazil: Embrapa Arroz e Feijão.

Nyquist, W.E., 1991. Estimation of heritability and prediction of selection response in plant population. Crit Rev Plant Sci 10, 235-322.

Oliveira, E.C., Costa, J.M.N., Paula Junior, T.J., Ferreira, W.P.M., Justino, F.B., Neves, L.O., 2012. The performance of the CROPGRO model for bean (Phaseolus vulgaris L.) yield simulation. Acta Sci. Agron. 34, 239-246, http://dx.doi.org/10. 4025/actasciagron.v34i3.13424.

Porch, T.G., 2006. Application of stress indices for heat tolerance screening of common bean. J. Agron. Crop Sci. 192, 390-394.

Prasad, P.V.V., Boote, K.J., Allen Jr., L.H., Thomas, J.M.G., 2003. Effects of elevated temperature and carbon dioxide on seed-set and yield of kidney bean (Phaseolus vulgaris L.). Global Change Biol. 8, 710-721.

R Core Team, 2015. R: A Language and Environment for Statistical Computing. R Foundation for Statistical Computing, Vienna, Austria http://www.R-project. org/.

Rainey, K.M., Griffiths, P.D., 2005. Inheritance of heat tolerance during reproductive development in snap bean (Phaseolus vulgaris L.). J. Am. Soc. Hortic. Sci. 130, 700-706.

Rao, I.M., 2001. Role of physiology in improving crop adaptation to abiotic stresses in the tropics: the case of common bean and tropical forages. In: Pessarakli, M. (Ed.), Handbook of Plant and Crop Physiology. Marcel Dekker, New York, pp. 583-613.

Reatto, A., Correia, J.R., Spera, S.T., Chagas, C.S., Martins, E.S., Andahur, J.P., Godoy, M.J.S., Lopes Assad, M.L. 2000. Levantamento pedológico semidetalhado da Bacia do Rio Jardim (DF): ficha de descrição dos perfis e mapa de solos da bacia do Rio Jardim, DF (escala 1:50.000). Planaltina, DF, Brazil: Embrapa.

Richardson, C.W., Wright, D.A., 1984. WGEN: A Model for Generating Daily Weather Variables. US Department of Agriculture, Washington, DC.

Ritchie, J.T., 1998. Soil water balance and plant stress. In: Tsuji, G.Y., Hoogenboom, G., Thornton, P.K. (Eds.), Understanding Options for Agricultural Production. Kluwer, Dordrecht The Netherlands, pp. 41-54.

Rosales-Serna, R., Kohashi-Shibata, J., Acosta-Gallegos Á, J., Trejo-López, C., Ortiz-Cereceres, J., Kelly, J.D., 2004. Biomass distribution, maturity acceleration and yield in drought-stressed common bean cultivars. Field Crop. Res. 85, 203-211, http://dx.doi.org/10.1016/S0378-4290(03)00161-8.
Singh, S.P., Schwartz, H.F., 2010. Breeding common bean for resistance to diseases: a review. Crop Sci. 50, 2199-2223, http://dx.doi.org/10.2135/cropsci2009.03. 0163.

Singh, S.P., 2001. Broadening the genetic base of common bean cultivars: a review. Crop Sci. 41, 1659-1675, http://dx.doi.org/10.2135/cropsci2001.1659.

Souza, T.L.P.O., Faleiro, F.G., Dessaune, S.N., Paula-Junior, T.J., Moreira, M.A., Barros, E.G., 2013. Breeding for common bean (Phaseolus vulgaris L.) rust resistance in Brazil. Trop. Plant Pathol. 38, 361-374, http://dx.doi.org/10.1590/S198256762013005000027.

Spera, ST, Reatto A, Martins ES, Correia Jr., 2005. Atributos físicos de solos e distribuição das fitofisionomias de cerrado na bacia hidrográfica do Rio Jardim, DF., Planaltina, DF, Brazil: Embrapa Cerrados.

Teixeira, G.C.S., Stone, L.F., Heinemann, A.B., 2015. Eficiência do uso da radiação solar e índices morfofisiológicos em cultivares de feijoeiro. Pesqui. Agropecu. Tropical 45, 9-17.

Thung, M., Rao, I.M., 1999. Integrated management of abiotic stresses. In: Singh, S.P. (Ed.), Common Bean Improvement in the Twenty-first Century. Kluwer, Dordrecht The Netherlands, pp. 331-370.

Vandenberg, A., Nleya, T., 1999. Breeding to improve plant type. In: Singh, S.P. (Ed.), Common Bean Improvement in the Twenty-first Century. Kluwer, Dordrecht The Netherlands, pp. 185-222.

Vilhordo, B.W., Mikusinski, O.M.F., Burin, M.E., Gandolfi, V.H., 1996. Morfologia. In: Araujo, R.S., Rava, C.A., Stone, L.F., Zimmermann, M.J.O. (Eds.), Cultura Do Feijoeiro Comum No Brasil. Potafos, Piracicaba, Brazil, pp. 71-99.

Wander, A.E., 2007. Produção e consumo de feijão no Brasil, 1975-2005. Informações Econômicas 37, 7-21.

Ward, J.H., 1963. Hierarchical grouping to optimise an objective function. J. Am. Stat. Assoc. 58, 236-244.

Webber, H.A., Madramootoo, C.A., Bourgault, M., Horst, M.G., Stulina, G., Smith, D.L., 2010. Adapting the CROPGRO model for saline soils: the case for a common bean crop. Irrig. Sci. 28, 317-329, http://dx.doi.org/10.1007/s00271009-0189-5.

White, J.W., Hoogenboom, G., Jones, J.W., Boote, K.J., 1995. Evaluation of the dry bean model Beangro V1.01 for crop production research in a tropical environment. Exp. Agric. 31, 241-254, http://dx.doi.org/10.1017/ S001447970002531X

White, J.W., Izquierdo, J., 1991. Physiology of yield potential and stress tolerance. In: Schoonhoven, A., Voysest, O. (Eds.), Common Beans Research for Crop Improvement. CAB International, Wallingford, UK.

Williams, W.T., 1976. Pattern Analysis in Agricultural Science. Elsevier, Amsterdam. 